\title{
HTR1B as a risk profile maker in psychiatric disorders: a review through motivation and memory
}

\author{
Antonio Drago • Silvia Alboni • Brunello Nicoletta • \\ Diana De Ronchi • Alessandro Serretti
}

Received: 2 July 2009 /Accepted: 18 August 2009 / Published online: 7 October 2009

(C) Springer-Verlag 2009

\begin{abstract}
Purpose Serotonin receptor 1B (HTR1B) is involved in the regulation of the serotonin system, playing different roles in specific areas of the brain. We review the characteristics of the gene coding for HTR1B, its product and the functional role of HTR1B in the neural networks involved in motivation and memory; the central role played by HTR1B in these functions is thoroughly depicted and show HTR1B to be a candidate modulator of the mnemonic and motivationally related symptoms in psychiatric illnesses.

Methods In order to challenge this assessment, we analyze how and how much the genetic variations located in the gene that codes for HTR1B impacts on the psychiatric phenotypes by reviewing the literature on this topic.

Results We gathered partial evidence arising from genetic association studies, which suggests that HTR1B plays a relevant role in substance-related and obsessive compulsive disorders. On the other hand, no solid evidence for other psychiatric disorders was found. This finding is quite striking because of the heavy impairment of motivation and of mnemonic-related functions (for example, recall bias) that characterize major psychiatric disorders.

Conclusions The possible reasons for the contrast between the prime relevance of HTR1B in regulating memory and motivation and the limited evidence brought by genetic association studies in humans are discussed, and some suggestions for possible future directions are provided.
\end{abstract}

A. Drago $\cdot$ D. De Ronchi $\cdot$ A. Serretti $(\bowtie)$

Institute of Psychiatry, University of Bologna,

Viale Carlo Pepoli 5,

40123 Bologna, Italy

e-mail: alessandro.serretti@unibo.it

S. Alboni $\cdot$ B. Nicoletta

Department of Biomedical Sciences,

University of Modena and Reggio Emilia,

Modena, Italy
Keywords Memory · Motivation · Receptor - Serotonin · 5-HT1B · Gene · Single nucleotide polymorphism ·

Psychotic disorder - Bipolar disorder - Obsessive-compulsive disorder $\cdot$ Substance-related disorders $\cdot$ Suicide

\section{Introduction}

The serotonin system regulates a wide spectrum of neuronal activities, with its influence reverberating into physiological events as diverse as body temperature, mood level, hormone release, food intake, sleep balance and learning abilities. This relevance is based upon a vast network of serotonergic connections that reach virtually the whole central nervous system and are orchestrated by the activities of at least 14 known distinct serotonin receptors. The detailed knowledge of the characteristics of the serotonin receptors will hopefully shed some light on the mechanisms that underlie psychiatric disorders. Based on this rationale, a wide range of genetic investigations have been performed so far that could nevertheless still not produce conclusive results. The unraveling of the reasons for this incomplete result is a relevant topic in contemporary scientific debate. Starting from this perspective, we here retrace the reasons why one of these receptors, HTR1B, can be considered a good candidate to be a putative regulator of psychiatric disorders, and we compare this set of evidence with the results brought by the genetic association studies focused on HTR1B mutations. Collecting the first set of evidence, motivation and memory functions in animal models were chosen as relevant points in the analysis of HTR1B functional relevance, because:

1. Memory and motivation are high brain functions impaired in many psychiatric phenotypes.

2. Animal models allow a refined experimental modulation of HTR1B activities and there are animal tests that are considered to be good models for these functions in humans. 
The limits and advantages of this translational approach are critically discussed. The results of the genetic association analyses are then reported and discussed. The inconsistency between the relevant role of HTR1B and the genetic association results are discussed.

\section{Materials and methods}

Information on the HTR1B as a gene and as a receptor, and on the associations between the genetic variations and the protein functions is drawn from international databases (www.geneontology.org; www.genecards.org; www. ensembl.org; www.pdb.org; http://www.ncbi.nlm.nih.gov/).

The first part of the paper is a reasoned review of the evidence on motivation and memory as products of the functions of specific neural networks. Then, the functional impact of HTR1B on these dimensions is depicted. For this part of the review, we searched the literature in April 2009 using the following databases: PubMed, EMBASE, International Pharmaceutical Abstracts (IPA) and Web of Science. These were searched using the following items: "HTR1B," "serotonin receptor 1b," "5-HT1B," "agonist," "antagonist," "animal model," "mice" and "mouse" in combination. The same databases were searched for the second part of the review, which focuses on the genetic association studies. The following terms were searched for: "HTR1B," "serotonin receptor 1b," "5-HT1B," "depressive disorder," "anxiety disorder," "schizophrenia," "psychotic disorder," "eating disorder," "suicide behaviour," "obsessive compulsive disorder," "substance related disorder," "dependence," "abstinence," "genetic variation," "SNP" and "polymorphism," and "genetic variation" in combination.

\section{HTR1B as a gene}

The HTR1B gene is located on chromosome 6 at position 78,228,641-78,229,900 (http://www.ensembl.org/Homo sapiens/index.html). It contains one exon and codes for a 1,260 bps transcript. The gene's transcript produces one product with no known isoforms. Table 1 reports the most relevant variation within the exon sequence of HTR1B along with their frequencies on the HapMap populations. Only eight exonic variations are listed in Table 1 that are nevertheless of prime relevance for further investigations into this gene in that they directly change the amino-acidic sequence of the receptor, thus causing variations in its $3 \mathrm{D}$ structure, which is tightly associated with its functions. Thus, further investigations should include those variations in their analysis. Nevertheless, intronic variations may be relevant as well in that they are able to change the regulatory profile of the gene, thus impacting on the receptor's density on the surface of the cells. Table 2 lists the entire sequence of the gene and highlights the most relevant variations. Figure 1 shows some of the most relevant coding mutations and their location near to, or within, the genetic frame that code for putative functional enzymatic sites. The number of validated variations localized in the HTR1B is 44. The number of tagging variations in the CEU AND YRI populations is 1 (rs6298), rs6296 is a tagging variation in the CHB and JPT populations. Of note, rs6298, rs130060 and rs6296 are characterized by a relevant frequency in the general population. They give rise to changes in positions 43,124 and 287 respectively. Substitution in position 124 is nonsynonymous and it leads to a Cys to Phe change, corresponding to alleles $\mathrm{G}$ and $\mathrm{T}$ respectively. Both amino-acids are non-polar and have a similar hydropathy index (2.5 and 2.8 respectively). The precise role of this mutation is awaiting definition. Four variations can tag HTR1B in the CEU population: rs11568817, rs6298, rs4140535 and rs130058. Other relevant mutations are the Phe219Leu, Ile367Val and Glu374Lys; these could potentially affect ligand binding or interaction with $G$ proteins [143]. The majority of these variations were not investigated in psychiatric disorders (Tables 3, 4, 5, 6, 7). Finally, HTR1D, HTR1E and HTR1F are known as the paralogs of HTR1B, that is, genes that are related by duplication to HTR1B, but have evolved different functions.

\section{Possible relevance of HTR1B mutations in the pharmacodynamics of antidepressant and antipsychotic drugs}

The genetic variations of HTR1B can result in events related to the pharmacodynamics of antidepressant or antipsychotic events in different ways:

1. A mutation that changes the amino-acidic sequence of the receptor can determine an altered enzymatic function, either because located in the enzymatic active site of the receptor, or because able to change the 3D structure of the receptor, thus interfering with its function.

2. A mutation located in the regulatory sites of the gene can change its expression rate, thus causing a variation in the density of the receptor on the surface of neurons, with consequences for the dynamics of drugs that directly or indirectly act on the HTR1B coded protein.

It has been demonstrated that the second extracellular loop and the fifth transmembrane domain of the HTR1B receptor is necessary to and sufficient for the binding function of the HTR1B receptor [183]. Thus, variations occurring in parts of the gene that code for these aminoacidic sequences are candidate modulators of the functions 
Table 1 HTR1B exonic variations and their frequencies at HapMap populations

\begin{tabular}{|c|c|c|c|c|c|c|c|c|c|c|c|}
\hline \multirow[t]{2}{*}{ Residue } & \multirow[t]{2}{*}{ SNP ID } & \multirow[t]{2}{*}{ SNP type } & \multirow[b]{2}{*}{ Alleles } & \multicolumn{2}{|l|}{ CEU } & \multicolumn{2}{|l|}{$\mathrm{HCB}$} & \multicolumn{2}{|l|}{ JPT } & \multicolumn{2}{|l|}{ YRI } \\
\hline & & & & 1 & 2 & 1 & 2 & 1 & 2 & 1 & 2 \\
\hline 43 & rs6298 & Synonymous & $\mathrm{C} / \mathrm{T}$ & 0.66 & 0.34 & 0.467 & 0.533 & 0.433 & 0.567 & 0.758 & 0.242 \\
\hline 92 & rs 130059 & Synonymous & $\mathrm{A} / \mathrm{G}$ & No data* & No data & No data & No data & No data & No data & No data & No data \\
\hline 124 & rs130060 & Non-synonymous & $\mathrm{G} / \mathrm{T}$ & 0.50 & 0.50 & 0.50 & 0.50 & 0.50 & 0.50 & 0.50 & 0.50 \\
\hline 219 & rs 130061 & Non-synonymous & $\mathrm{C} / \mathrm{T}$ & 0.00 & 1.00 & 0.00 & 1.00 & 0.01 & 0.99 & 0.00 & 1.00 \\
\hline 235 & rs 130062 & Synonymous & $\mathrm{C} / \mathrm{T}$ & No data** & No data & No data & No data & No data & No data & No data & No data \\
\hline 287 & rs6296 & Synonymous & $\mathrm{C} / \mathrm{G}$ & 0.34 & 0.66 & 0.54 & 0.46 & 0.57 & 0.43 & 0.24 & 0.76 \\
\hline 367 & rs 130063 & Non-synonymous & $\mathrm{A} / \mathrm{G}$ & 1.00 & 0.00 & 0.97 & 0.03 & 0.99 & 0.01 & 1.00 & 0.00 \\
\hline 374 & rs 130064 & Non-synonymous & $\mathrm{C} / \mathrm{T}$ & 0.00 & 1.00 & 0.01 & 0.99 & 0.00 & 1.00 & 0.00 & 1.00 \\
\hline
\end{tabular}

1 Allele 1 is the first allele that is reported in the column "alleles," for example, allele 1 at rs6298 is C

2 Variations with interesting frequencies in the populations are in bold

There is inconsistent reporting with regard to allele types from NCBI to Ensembl. NCBI data are reported

*Populations other than the HapMap population report a higher frequency for the $\mathrm{G}$ allele

**Populations other than the HapMap population report a higher frequency for the $\mathrm{C}$ allele

of the receptor. Moreover, events related to the regulation of the expression rate of HTR1B are closely associated with the antidepressant effect of the pharmaco-treatment of depression; paroxetine and fluoxetine determine a downregulation of the HTR1B mRNA expression in the serotonergic neurons whose cell bodies are located in the dorsal raphe nucleus in mice [3], an event that is thought to be directly correlated with the antidepressant efficacy of these drugs [156]. Consequently, a mutation located in the regulatory regions of the HTR1B may be able to enhance or dampen the effects of these drugs, by the way of a genetically determined increased or decreased flexibility in the regulation of the genetic expression rates, which are the targets of the antidepressant treatments. Nevertheless, the mechanisms of antidepressant action are likely much more complicated. For example, in a recent study conducted by Orsetti and colleagues [114], the antidepressant activity of the second generation antipsychotic quetiapine was associated with an altered expression pattern of a list of 11 genes (namely: tgs2, Gad1, Plcb1, Camk2a, Homer1, Senp2, Junb, Nfib, Hes5, Capon, and Marcks) in the frontal cortex of mice. These genes code for proteins involved in second messenger activities or act as regulators of transcriptional events. Notably, none of the receptors of the serotonin system is present, even though the serotonin regulation could be indirectly associated with the activity of these proteins. Moreover, it must be underlined that these effects have been identified in the prefrontal cortex, whilst the raphe nucleus has not been investigated by Orsetti and colleagues. This may explain the different result attained by Anthony et al. [3] and Orsetti et al. [114], and may suggest that the brain might react to the antidepressant treatment in ways that are highly specific with respect to the brain area under analysis.

\section{HTR1B as a protein}

HTR1B is 390 amino-acids long and it weighs $43,568 \mathrm{Da}$. As an active enzyme it is located within the cellular membrane and it belongs to the super-family of the multi-pass membrane proteins. The $3 \mathrm{D}$ model is shown in Fig. 1; the active parts of the protein are highlighted and correlated with the coding mutations that characterize the gene. HTR1B functionally couples with a $\mathrm{G}_{\mathrm{I} / 0}$ protein, the activation of which results in two main metabolic events: a decreased level of cAMP (cyclic AMP), and the inhibition of the RAP1 guanine nucleotide exchange factor (Rap1GAP) activity.

\section{A HITR1B-driven decreased level of cAMP}

A decreased intracellular concentration of cAMP drives a diminished activation of the protein kinase A, a group of serine/threonine protein kinases that catalyze the reaction $<$ ATP + a protein $=$ ADP + a phosphoprotein $>>$ upon a set of cytosolic and nuclear protein products. The phosphorylation of a protein drives its activity profile; the refined orchestration of the PKA-dependent phosphorylation events upon key enzymatic factors decide a cell's fate by regulating transcription [79, 140], metabolism [47], cell cycle progression [103, 152], and apoptosis [19, 44].

\section{A HITR1B-driven inhibition of the Rap1GAP activity}

RAP1GAP activates the RAP1, a member of the Ras family of small GTPases, and favors switching to the RAP1 state, which hydrolyzes GTP to GDP [68]. This reaction can be reversed by the GEF (guanine nucleotide exchange factors) 
Table 2 HTR1B sequence and most relevant variations (Ensembl database)

\begin{tabular}{|c|c|c|c|}
\hline $\begin{array}{c}\text { Number of } \\
\text { base }\end{array}$ & Bases and mutated bases & $\begin{array}{l}\text { Corresponding } \\
\text { mutation }\end{array}$ & $\begin{array}{c}\text { Corresponding } \\
\text { SNP }\end{array}$ \\
\hline 1 & AGCTCGTCCGAGTGGCCAGAGAGTGAAAAGAGAGGGAGGGCAGAGCTCCGGCGCGAGRCG & $58: G / A$ & RS11965950 \\
\hline 61 & CGGCGCAGCGCTGCTCCTAGACTTCACCCCACCCAGCTCTGGCGGCCGCTGCAGCCCCCC & & \\
\hline 121 & AAAAGTGCCCCAGCTTGGGGCGAGGGGTGGKAATGCAAGATCTCGGGACCTCTCGCTGGC & $151: \mathrm{G} / \mathrm{T}$ & rs130056 \\
\hline 181 & CTGCAAGCTTTGGTCTCTACACCTAGGAAACTCCTGTGGGCAAAGTCTGCAGATCCAAAA & & \\
\hline 241 & GCGTCCAGGTTAGGAGACGCTCAGCCTCAAGCAACTGGGGTAAGAGATCCCATTTGGTCA & & \\
\hline 301 & 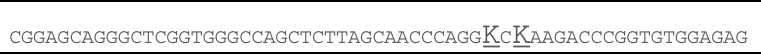 & $\begin{array}{l}400: \mathrm{T} / \mathrm{G} ; \\
402: \mathrm{T} / \mathrm{G} ;\end{array}$ & $\begin{array}{l}\text { rs11568817; } \\
\text { rs11575885 }\end{array}$ \\
\hline 421 & GAACAW $\underline{W} C C A C A G A C G C G G C G G C T T A G C T A G G C G C T C T G G A A G T G C A G G G G A G G C G C C C G C$ & $\begin{array}{c}426: \mathrm{A} / \mathrm{T} ; \quad 480:- \\
/ \mathrm{CC} ;\end{array}$ & $\begin{array}{l}\text { rs34311679; } \\
\text { rs34401185 }\end{array}$ \\
\hline 481 & 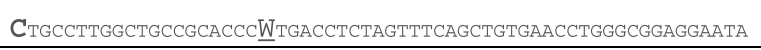 & $501: \mathrm{A} / \mathrm{T} ;$ & rs130058 \\
\hline 541 & ATTGAGGAACTCACGGAACTATCAACTGGGGACAAACCTGCGATCGCCACGGTCCTTCCG & & \\
\hline 601 & ссСтCTCCTTCGTCCR्RCTCCATGCCCAAGAGCTGCGCTCCGGAGCTGGGGCGAGGAGAGC & $616: G / A$ & rs34514827 \\
\hline 661 & CATGGAGGAACCGGGTGCTCAGTGCGCTCCACCGCCGCCCGCGGGCTCCGAGACCTGGGT & & \\
\hline 721 & TCCTCAAGCCAACTTATCCTCTGCTCCCTCCCAAAACTGCAGCGCCAAGGACTACATTTA & & \\
\hline 781 & CCAGGACTCY $\underline{Y}$ ATCTCCCTACCCTGGAAAGTACTGCTGGTTATGCTATTGGCGCTCATCAC & $790: \mathrm{C} / \mathrm{T}$ & rs6298 \\
\hline 841 & CTTGGCCACCACGCTCTCCAATGCCTTTGTGATTGCCACAGTGTACCGGACCCGGAAACT & & \\
\hline 901 & GCACACCCCGGCTAACTACCTGATCGCCTCTCTGGCR RTCACCGACCTGCTTGTGTCCAT & $937: G / A$ & rs130059 \\
\hline 961 & CCTGGTGATGCCCATCAGCACCATGTACACTGTCACCGGCCGCTGGACACTGGGCCAGGT & & \\
\hline 1021 & GGTCTGTGACT KCTGGCTGTCGTCGGACATCACTTGTTGCACTGCCTCCATCCTGCACCT & $1032: \mathrm{T} / \mathrm{G}$; & rs 130060 \\
\hline 1081 & CTGTGTCATCGCCCTGGACCGCTACTGGGCCATCACGGACGCCGTGGAGTACTCAGCTAA & & \\
\hline 1141 & AAGGACTCCCAAGAGGGCGGCGGTCATGATCGCGCTGGTGTGGGTCTTCTCCATCTCTAT & & \\
\hline 1201 & СTCGCTGCCGCCCTTCTTCTGGCGTCAGGCTAAGGCCGAAGAGGAGGTGTCGGAATGCGT & & \\
\hline 1261 & GGTGAACACCGACCACATCCTCTACACGGTCTACTCCACGGTGGGTGCTTTCTACYTCCC & $1316: \mathrm{T} / \mathrm{C}$ & rs130061 \\
\hline 1321 & CACCCTGCTCCTCATCGCCCTCTATGGCCGCATCTACGTAGAAGCY $\underline{\text { CGCTCCCGGATTTT }}$ & $1366: \mathrm{C} / \mathrm{T}$; & rs 130062 \\
\hline 1381 & GAAACAGACGCCCAACAGGACCGGCAAGCGCTTGACCCGAGCCCAGCTGATAACCGACTC & & \\
\hline 1441 & CCCCGGGTCCACGTCCTCGGTCACCTCTATTAACTCGCGGGTTCCCGACGTGCCCAGCGA & & \\
\hline 1501 & ATCCGGATCTCCTGTGTATGT S-SAACCAAGTCAAAGTGCGAGTCTCCGACGCCCTGCTGGA & $1522: G / C$ & $\begin{array}{c}\text { rs6296 (cited in } \\
\text { Pubmed at } \\
17948897 ; \\
15206000 \text { ) } \\
\end{array}$ \\
\hline 1561 & AAAGAAGAAACTCATGGCCGCTAGGGAGCGCAAAGCCACCAAGACCCTAGGGATCATTTT & & \\
\hline 1621 & GGGAGCCTTTATTGTGTGTTGGCTACCCTTCTTCATCATCTCCCTAGTGATGCCTATCTG & & \\
\hline 1681 & CAAAGATGCCTGCTGGTTCCACCTAGCCATCTTTGACTTCTTCACATGGCTGGGCTATCT & & \\
\hline 1741 & CAACTCCCTCATCAACCCCRTAATCTATACCATGTCCAATRAGGACTTTAAACAAGCATT & $\begin{array}{l}1760: \mathrm{A} / \mathrm{G} ; \\
1781: \mathrm{G} / \mathrm{A} ;\end{array}$ & $\begin{array}{l}r s 130063 ; \\
r s 130064\end{array}$ \\
\hline 1801 & CCATAAACTGATACGTTTTAAGTGCACAAGTTGACTTGCCRTTTGCAGTRGGGTCGCCTA & $\begin{array}{l}1841: \mathrm{G} / \mathrm{A} \\
1850: \mathrm{G} / \mathrm{A}\end{array}$ & $\begin{array}{c}\text { rs6297i } \\
\text { rs3827804 }\end{array}$ \\
\hline 1861 & AGCGACCTTTGGGGACCAAGTTGTGTCTGGTTCCACAGGTAGGTCGAATCTTCTTTCGCG & & \\
\hline 1921 & GTTTCTGGGTCCCAGCGAGGCTCTCTCTCCTGGGCAAGGGCAATGGATCCTGAGAAGCCA & & \\
\hline 1981 & GAATAGTCCTGAGAGAGAGCTCTGAAAGGAGAAGTGTTGAAACTAAATGTAGAGCTTCCC & & \\
\hline 2041 & TGCCCAGGAGGAGGCTCACTTCCTCCCCTCAAGCCCCGGGCTCAGCACTGACCCTGCGGY & $2100: \mathrm{C} / \mathrm{T}$ & rs9361234; \\
\hline 2101 & AGCCAATCCCAAAGGGGGTTGCAACTTTTAAAAATTGATAATGGAAGGGAATCCCTGCCC & & \\
\hline 2161 & TGCTTTGGTATCGTGGATAATGCCCACTAGAAGCAGTGTACTTGTAATTGTTGTCTGAAG & & \\
\hline 2221 & СCTGTCTGAGACAGATCTACATACAGCCTGGCAGTACTTGAACTAGACGCTTAATGCCCT & & \\
\hline 2281 & GTGTTTTT GGGGGGAGAACTTTGTGTTACAGCTTAATTTAAGAACAGTTACTTTGGCATC & $2289: \mathrm{GG} /-;$ & rs58138557 \\
\hline 2341 & ATTCAGTCTTCACTTTTTGTCTATTTAAACTTGGTTGGAGAAACTTGTGGATTTGGTGCT & & \\
\hline 2401 & TCAAACCCTATGTGTGGCTTGGATGGCGCAGAGAAACCTTGAAGAGTTAACAGCAAAATT & & \\
\hline
\end{tabular}

Underlined $=$ location of SNP; bold $=$ insertion; bold and underlined $=$ deletion 
[68]. At the neuronal level, the balance between GTP and GDP has been claimed to be part of the orchestration of the switch between proliferation, differentiation and neurite growth. In particular, the activated transcription of HTR1B results in enhanced neurite outgrowth of thalamic neurons, likely through the activity of $\mathrm{G}$ proteins, which switch from the activated to the de-activated state upon GTP $\rightarrow$ GDP exchange [99].

Where in the brain

As a protein, HTR1B is expressed mainly at the presynaptic level where it inhibits the neuronal firing as an autoreceptor. Moreover, it is expressed as a heteroreceptor on the surface of different neurons. HTR1D exerts the same activity as HTR1B, but it is likely mainly expressed at the post-synaptic level $[76,102]$. In the human brain HTR1B is expressed at high levels in the substantia nigra and in the globus pallidus. Lower levels are present in the striatum, with the highest densities in the ventromedial parts, in the amygdala, in the hippocampus and in the septal region of the hypothalamus. Low density of HTR1B are found in the cortex with the exception of the medial occipital cortex. HTR1D is less abundant than HTR1B, and it is especially expressed in the ventral pallidus [175]. A similar pattern of distribution can be found in mice [90].
Diverse functions in different parts of the brain

Overall, the ablation of HTR1B leads to impulsive aggressiveness and increased sexual behavior, along with increased alcohol and cocaine intake in animal models [42, $129,137,145]$. These phenotypes are dependent on intricate molecular activity across the central nervous system, with HTR1B providing activating or inhibiting effects according to the neuron's surface on which it is expressed; HTR1B activation on the surface of a GABAergic neuron would result in a final excitatory activity, whilst the expression of HTR1B on the surface of a serotonergic neuron functionally associated with a glutamatergic network would result in inhibitory activity. Consistent with this, there has been reported evidence that HTR1B plays an excitatory role with regard to serotonergic neurons in the raphe nucleus [58], that it acts with an excitatory final effect on GABAergic networks in the suprachiasmatic nucleus [24], and that it acts with an inhibitory final effect on serotonergic release on the striatum [45] and in the frontal cortex and hippocampus [169]. Quite interestingly HTR1B seems to enhance the serotonin transmission in the caudal parts of the brain, whilst it inhibits the serotonin transmission in the rostral parts of it. Things may be fairly complicated though; it has been suggested that the activating or inhibitory events following HTR1B stimulation may actually depend on the frequency of stimulation
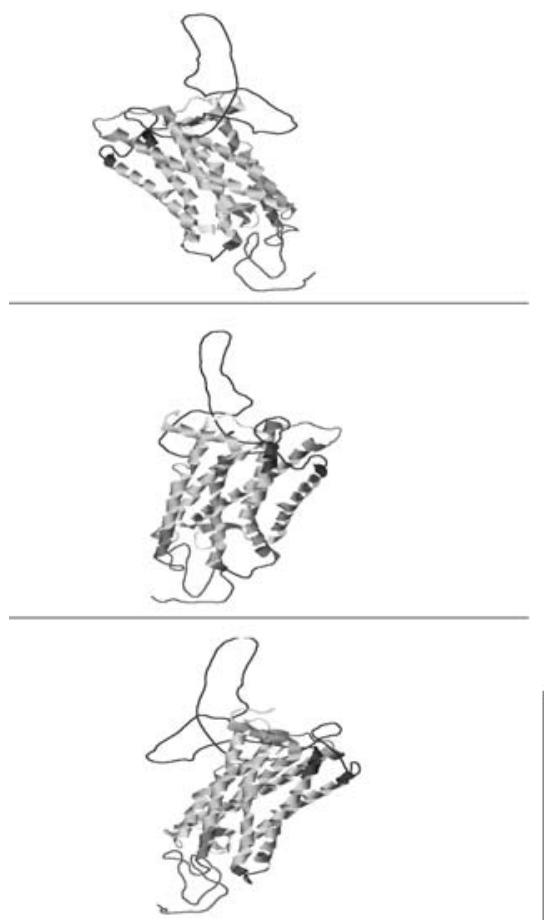

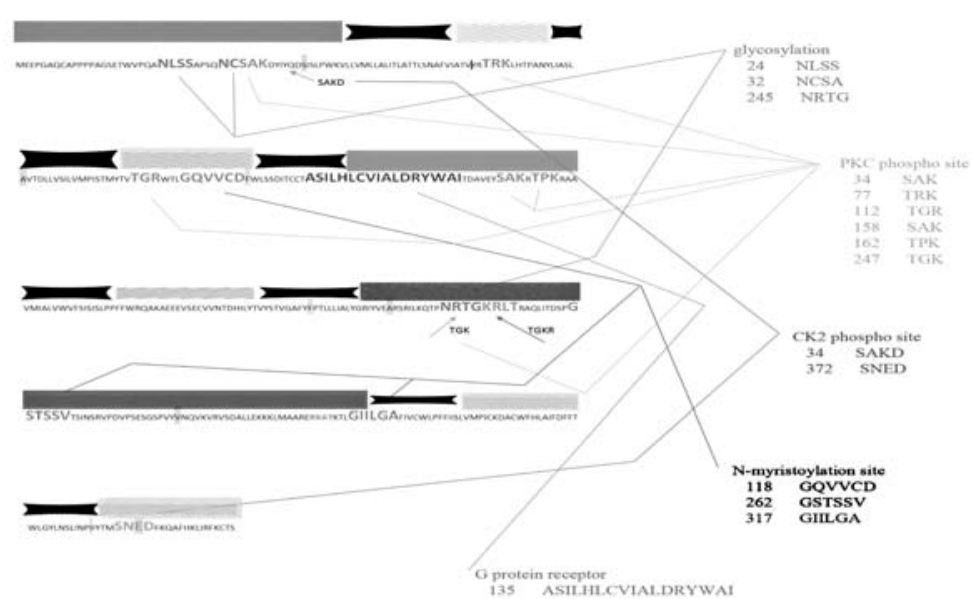

HTR1B 3d model is shown according to the PDB dataset "2G1X" (www.uniprot.org). In the left side of the picture, HTR1B receptor is seen from (roughly) front, left and rear side. The protein is shown while holding its $\mathrm{N}$ terminal at its south pole. The helices indicate the transmembrane parts of the receptor. In the center of the picture, the complete aminoacidic sequence of the receptor is reported along with the prevalent synonymous and non synonymous variations (www.ensemble.org). Interestingly, the last variaton labeled in the figure is located in the putative regulation side (CK2 phosphosite). In corresponds to variation $\mathrm{rs} 130064(\mathrm{C} / \mathrm{T})$ (www.ensemble.org). On the right site of the picture, the principal sites of regulation of the receptor are reported.

Fig. 1 HTR1B 3D molecular structure: the amino-acid sequence is shown. Relevant enzymatic sites are high lightened along with synonymous (shadowed underlined) and non synonymous (shadowed not underlined) variations 
Table 3 Genetic association studies unraveling the association between substance dependence disorders and HTR1B variations

\begin{tabular}{|c|c|c|c|c|c|}
\hline Reference & $\begin{array}{l}\text { Investigated } \\
\text { HTR1B snp }\end{array}$ & Sample & Ethnicity & Result & $P$ level \\
\hline$[35]$ & $\begin{array}{l}\text { A-161T; A1180G; } \\
\text { 184/- 183; - 182/- } \\
\text { 181; T-261G, } \\
\text { C129T, G861C }\end{array}$ & $\begin{array}{l}166 \text { subjects with cocaine abuse } \\
\text { or dependence or alcohol abuse } \\
\text { or dependence, } 44 \text { controls }\end{array}$ & $\begin{array}{l}\text { Caucasian }=91 \\
\text { African/ } \\
\text { American } 93 \\
\text { Hispanic }=26 \\
\text { Other }=10\end{array}$ & No significant association & Not significant \\
\hline$[88]$ & $\begin{array}{l}\text { G861C, G-261T, } \\
\text { C129T }\end{array}$ & $\begin{array}{l}347 \text { subjects suffering from } \\
\text { substance dependence and } 146 \\
\text { healthy controls }\end{array}$ & $\begin{array}{l}370 \text { Caucasian } \\
123 \text { African/ } \\
\text { Americans }\end{array}$ & $\begin{array}{l}\text { No significant association with } \\
\text { substance dependence or with } \\
\text { antisocial behavior }\end{array}$ & Not significant \\
\hline$[92]$ & G861C & $\begin{array}{l}242 \text { female smoking initiators } \\
\text { ( } 127 \text { with high and } 115 \text { with low } \\
\text { nicotine dependence), } 148 \\
\text { female smoking non-initiators }\end{array}$ & Caucasian & $\begin{array}{l}\text { G861C GG genotype was } \\
\text { associated with higher nicotine } \\
\text { dependence }\end{array}$ & $P=0.01 ; \mathrm{OR}=2.29$ \\
\hline$[78]$ & G861C & $\begin{array}{l}394 \text { psychiatric patients and } 96 \\
\text { healthy subjects }\end{array}$ & Caucasians mainly & $\begin{array}{l}\text { G861C C allele is associated with } \\
\text { abuse disorder and MDD }\end{array}$ & $P=0.007$ \\
\hline$[166]$ & $\begin{array}{l}\text { G-511T; -504Bgl } \\
\text { II; T-261G; A- } \\
\text { 161T; C129T; } \\
\text { A772G; G861C; } \\
\text { G1180A }\end{array}$ & $\begin{array}{l}158 \text { alcohol-dependent cases with } \\
\text { withdrawal symptoms and } 149 \\
\text { control subjects }\end{array}$ & Asians & $\begin{array}{l}\text { A-161T variant was found to be } \\
\text { marginally associated with } \\
\text { alcohol dependence: A allele } \\
\text { was less represented in cases }\end{array}$ & $\begin{array}{l}P=0.01 \text { (allele) } \\
P=0.041 \\
\text { (genotype) }\end{array}$ \\
\hline [89] & G861C; D6S284 & $\begin{array}{l}166 \text { alcoholic criminal offenders, } \\
261 \text { relatives, } 213 \text { healthy } \\
\text { controls. Southwestern American } \\
\text { Indian tribe }(n=418) \text { with a high } \\
\text { rate of alcoholism }\end{array}$ & Caucasian & $\begin{array}{l}\text { In Finnish sib pairs, antisocial } \\
\text { alcoholism showed significant } \\
\text { evidence of linkage to HTR1B } \\
\text { G861C. Alcoholic offenders } \\
\text { have significantly higher } \\
\text { HTR1B-861C allele frequency. } \\
\text { In the Southwestern American } \\
\text { Indian tribe, significant sib pair } \\
\text { linkage of antisocial alcoholism } \\
\text { to HTR1B G861C and to } \\
\text { D6S284 }\end{array}$ & $\begin{array}{l}P=0.04 \\
P=0.005 \\
P=0.01 \\
P=0.01\end{array}$ \\
\hline
\end{tabular}

Table 4 Genetic association studies unraveling the association between obsessive compulsive disorders and HTR1B variations

\begin{tabular}{|c|c|c|c|c|c|}
\hline Reference & $\begin{array}{l}\text { Investigated } \\
\text { HTR1B snp }\end{array}$ & Sample & Ethnicity & Result & $P$ level \\
\hline$[105]$ & G861C & 32 families of OCD patients & Caucasian & $\begin{array}{l}\text { The } \mathrm{G} \text { allele of the } \mathrm{G} 861 \mathrm{C} \text { was } \\
\text { overtransmitted to OCD patients }\end{array}$ & $P<0.006$ \\
\hline [106] & G861C; T371G & 121 families of OCD patients & Caucasian & $\begin{array}{l}\text { The G allele of the G861C was } \\
\text { overtransmitted to OCD patients }\end{array}$ & $P=0.02$ \\
\hline$[30]$ & G861C & 72 trios of OCD patients & Caucasian & $\begin{array}{l}\text { The } \mathrm{G} \text { allele of the G861C was associated } \\
\text { with worse obsessive symptoms, but not } \\
\text { with diagnosis }\end{array}$ & $P=0.034$ \\
\hline$[48]$ & G861C & 48 trios of OCD patients & Caucasian & No significant association & $\begin{array}{l}\text { Not } \\
\text { significant }\end{array}$ \\
\hline [93] & G861C & $\begin{array}{l}165 \text { consecutive female probands with } \mathrm{BN} \text {, } \\
45 \text { of which had either full or partial } \\
\text { OCD syndrome }\end{array}$ & Caucasian & $\begin{array}{l}\text { GG genotype was associated with full } \\
\text { diagnosis of OCD in bulimic patients }\end{array}$ & $P=0.01$ \\
\hline$[70]$ & G861C & 71 OCD patients, 129 controls & $\begin{array}{l}\text { Afrikaner } \\
\text { population }\end{array}$ & No significant association & $\begin{array}{l}\text { Not } \\
\text { significant }\end{array}$ \\
\hline
\end{tabular}

$\mathrm{OCD}=$ obsessive compulsive disorder; $\mathrm{BN}=$ bulimia nervosa 
Table 5 Genetic association studies unraveling the association between schizophrenia and HTR1B variations

\begin{tabular}{|c|c|c|c|c|c|}
\hline Reference & Investigated HTR1B snp & Sample & Ethnicity & Result & $P$ level \\
\hline$[74]$ & A-161T & $\begin{array}{l}110 \text { schizophrenics and } \\
215 \text { controls }\end{array}$ & Asian & $\begin{array}{l}\text { No significant association } \\
\text { with schizophrenia }\end{array}$ & Not significant \\
\hline$[52]$ & $\begin{array}{l}\text { T-261G, }-182 \mathrm{INS} / \mathrm{DEL}-181 \text {, } \\
\mathrm{A}-161 \mathrm{~T}, \mathrm{C} 129 \mathrm{~T} \text { and G861C }\end{array}$ & $\begin{array}{l}456 \text { schizophrenics and } \\
557 \text { controls; } 229 \text { trios }\end{array}$ & Asian & $\begin{array}{l}\text { No significant association } \\
\text { with schizophrenia }\end{array}$ & Not significant \\
\hline$[78]$ & G861C & $\begin{array}{l}394 \text { psychiatric patients and } 96 \\
\text { healthy subjects }\end{array}$ & Caucasians mainly & $\begin{array}{l}\text { No significant association with } \\
\text { schizophrenia }\end{array}$ & Not significant \\
\hline
\end{tabular}

Table 6 Genetic association studies unraveling the association between suicidal behavior and HTR1B variations

\begin{tabular}{|c|c|c|c|c|c|}
\hline Reference & Investigated HTR1B snp & Sample & Ethnicity & Result & $P$ level \\
\hline [176] & $\begin{array}{l}\text { Four polymorphisms within } \\
\text { three genes. The } \\
\text { polymorphism related to } \\
\text { the HTR1B was not } \\
\text { polymorphic }\end{array}$ & $\begin{array}{l}226 \text { suicide victims and } 225 \text { healthy } \\
\text { control subjects }\end{array}$ & Caucasian & $\begin{array}{l}\text { No significant association } \\
\text { with suicidal behavior }\end{array}$ & $\begin{array}{l}\text { Not } \\
\text { significant }\end{array}$ \\
\hline [141] & G861C & $\begin{array}{l}148 \text { suicide attempters and } 327 \text { healthy } \\
\text { controls }\end{array}$ & Caucasian & $\begin{array}{l}\text { No significant association } \\
\text { with suicidal behavior, or } \\
\text { with suicide method or } \\
\text { comorbidity }\end{array}$ & $\begin{array}{l}\text { Not } \\
\text { significant }\end{array}$ \\
\hline$[85]$ & G861C & $\begin{array}{l}\text { Meta-analysis involving } 789 \text { cases and } \\
1,247 \text { control subjects }\end{array}$ & Various & $\begin{array}{l}\text { No significant association } \\
\text { with suicidal behavior }\end{array}$ & $\begin{array}{l}\text { Not } \\
\text { significant }\end{array}$ \\
\hline [173] & G861C & $\begin{array}{l}106 \text { suicide completers and } 120 \text { normal } \\
\text { controls }\end{array}$ & Caucasian & $\begin{array}{l}\text { No significant association } \\
\text { with suicidal behavior }\end{array}$ & $\begin{array}{l}\text { Not } \\
\text { significant }\end{array}$ \\
\hline [110] & G861C & $\begin{array}{l}163 \text { suicide victims and } 163 \text { healthy } \\
\text { controls }\end{array}$ & Japanese & $\begin{array}{l}\text { No significant association } \\
\text { with suicidal behavior }\end{array}$ & $\begin{array}{l}\text { Not } \\
\text { significant }\end{array}$ \\
\hline$[164]$ & G861C & 363 suicide victims and 440 controls & Caucasian & $\begin{array}{l}\text { No significant association } \\
\text { with suicidal behavior }\end{array}$ & $\begin{array}{l}\text { Not } \\
\text { significant }\end{array}$ \\
\hline [187] & $\begin{array}{l}\text { Five } 5 \text {-HT1B loci, including } \\
\text { the A-161T }\end{array}$ & 338 suicide victims and 358 controls & Caucasian & $\begin{array}{l}\text { A-161T was associated with } \\
\text { aggressive behavior }\end{array}$ & $P<0.05$ \\
\hline [172] & A-161T & $\begin{array}{l}160 \text { MDD patients and } 160 \text { normal } \\
\text { controls }\end{array}$ & Asian & $\begin{array}{l}\text { No significant association } \\
\text { with suicidal behavior or } \\
\text { with MDD or fluoxetine } \\
\text { response }\end{array}$ & $\begin{array}{l}\text { Not } \\
\text { significant }\end{array}$ \\
\hline$[74]$ & A-161T & $\begin{array}{l}110 \text { schizophrenic patients and } 215 \\
\text { normal controls }\end{array}$ & Asian & $\begin{array}{l}\text { No significant association } \\
\text { with suicidal behavior or } \\
\text { with aggressive behavior }\end{array}$ & $\begin{array}{l}\text { Not } \\
\text { significant }\end{array}$ \\
\hline$[78]$ & G861C & $\begin{array}{l}394 \text { psychiatric patients and } 96 \text { healthy } \\
\text { volunteers }\end{array}$ & Asian & $\begin{array}{l}\text { No significant association } \\
\text { with suicide, } \\
\text { schizophrenia, alcoholism, } \\
\text { bipolar disorder }\end{array}$ & $\begin{array}{l}\text { Not } \\
\text { significant }\end{array}$ \\
\hline$[122]$ & G861C & $\begin{array}{l}129 \text { deliberately self-harming subjects, } \\
329 \text { controls }\end{array}$ & Caucasian & $\begin{array}{l}\text { No significant association } \\
\text { with self harming }\end{array}$ & $\begin{array}{l}\text { Not } \\
\text { significant }\end{array}$ \\
\hline$[77]$ & G861C; C129T & $\begin{array}{l}71 \text { suicide victims; } 107 \text { non-suicides; } \\
45 \text { MDD, } 79 \text { non-MDD; } 64 \text { substance } \\
\text { disorders, } 60 \text { without; } 36 \text { with patho } \\
\text { logical aggression, } 42 \text { without }\end{array}$ & $\begin{array}{l}\text { Caucasian } \\
\text { mainly }\end{array}$ & $\begin{array}{l}\text { No association between } \\
\text { gene and suicide; G allele } \\
\text { was associated with lower } \\
\text { 5-HT1B receptor binding }\end{array}$ & $\begin{array}{l}\text { Not } \\
\text { significant }\end{array}$ \\
\hline$[110]$ & G861C & 163 suicide victims & Asian & No significant association & $\begin{array}{l}\text { Not } \\
\text { significant }\end{array}$ \\
\hline [108] & G861C & 145 patients with personality disorder & $\begin{array}{l}\text { Caucasian }=90 \\
\text { Hispanic }=27 \\
\text { African/ } \\
\text { American }=24 \\
\text { Other }=4\end{array}$ & $\begin{array}{l}\text { The G allele associated with } \\
\text { a history of suicide } \\
\text { attempts in white patients } \\
\text { with personality disorders }\end{array}$ & $P=0.01$ \\
\hline
\end{tabular}


Table 7 Genetic association studies unraveling the association between personality disorders and HTR1B variations

\begin{tabular}{|c|c|c|c|c|c|}
\hline Reference & $\begin{array}{l}\text { Investigated HTR1B } \\
\text { snp }\end{array}$ & Sample & Ethnicity & Result & $P$ level \\
\hline [171] & A-161T & $\begin{array}{l}209 \text { young healthy } \\
\text { subjects }\end{array}$ & Chinese & $\begin{array}{l}\text { No significant association with } \\
\text { schizophrenia }\end{array}$ & Not significant \\
\hline$[160]$ & G861C & 164 alcoholic subjects & Caucasian & $\begin{array}{l}\mathrm{C} \text { allele was associated with antisocial } \\
\text { personality }\end{array}$ & $\begin{array}{l}P=0.042 \text { (Bonferroni } \\
\text { correction) }\end{array}$ \\
\hline
\end{tabular}

[178], which may provide the neural networks with a refined tool to balance the noise-signal ratio.

\section{From animals to humans: HTR1B in a translational approach}

\section{KO models}

The body of knowledge about the postulated role of the HTR1B receptor in regulating brain functions, physiological processes, complex behaviors [130, 146], and possibly in participating in the genesis of several psychopathological conditions $[34,55,62,150]$ mainly comes from pre-clinical studies.

These pre-clinical studies include in vivo or in vitro pharmacological treatments with selective HTR1B receptor agonists and/or antagonists followed by the evaluation of specific neurochemical parameters and/or behavioral tests. Moreover, besides the use of pharmacological tools, the neurochemical setting and the response to specific behavioral tests have been evaluated in genetically modified animal mouse models such as constitutive knockout (KO) mice lacking HTR1B receptor generated by homologous recombination [145].

Since the early 1990 s genetically modified rodents have been used to identify basal functions and behaviors impaired by the mutation of a gene of interest and thus the role of a specific protein. There are many advantages of using genetically-engineered mice to assess the influence of a given gene on a specific molecular target and/or specific behavior in a direct way. For example:

1. In mice the genetic background can be controlled and its genome is easily manipulable.

2. Cutting-edge technologies (including invasive ones) can be used.

3. A large number of biological functions of the mouse are similar to those of the human.

Mice lacking the HTR1B receptor subtype exhibit different changes in phenotypes, suggesting a major role for this serotonergic receptor subtype in mediating many functions (for a review of main phenotypic features see [162]). HTR1B KO mice do not exhibit any, or have few, obvious developmental and behavioral defects in the absence of environmental or pharmacological challenges [37, 129, 145, 146]. However, by conducting behavioral tests, it has been demonstrated that these HTR1B KO mice show, among other less striking behavioral phenotypes, lower anxiety [66, 129], and increased aggressive behavior [145] and impulsivity [23] compared with its wild type (WT) control strain. These KO mice could be considered an animal model for the disease state of increased vulnerability to drug abuse, such as cocaine [136, 137], or to psychiatric disorders [56, 146, 186].

However, even if constitutive HTR1B KO mice are an extremely powerful tool in the study of the role of the HTR1B receptor in the brain, care must be taken in the interpretation of the data obtained using these mice. In fact, in the $\mathrm{KO}$ animals, the gene is negated during the embryonic stage and is thereafter absent for the entire life of the organism. The life-long ablation of the receptor causes compensatory changes to occur in the HTR1B KO mice that should be taken into consideration before drawing any conclusions regarding the analysis of the mutant phenotype. Compensatory changes that have been demonstrated in HTR1B KO mice affect different neurotransmitter systems in the brain such as the serotonergic [38, 62], the dopaminergic [6, 153], and the cholinergic [142] systems. These changes include altered neurotransmitter release $[121,169,170]$ or turnover [6], rather than modify receptor expression or mediated functions $[38,61]$ in specific brain regions. In this regard, intracellular pathways transducing the receptor-mediated signal into the cells could also be affected by the life-long knockout of the gene. For example, Ase and colleagues found that the efficacy of G-protein coupling to HTR1A [5], mu-opioid and GABAB [6] receptors is decreased in HTR1B KO mice. Long-term receptor absence induces changes in gene expression as well. HTR1B KO mice have elevated striatal levels of $\Delta$ FosB and increased AP1 DNA-binding activity compared with their WT litter-mates [137].

On the whole, these compensatory responses to the constitutive deletion of HTR1B receptors are very likely to underlie some of the behavioral phenotypes observed in the HTR1B KO mice. Moreover, these regionally selective compensatory changes may contribute to explaining some of the observed discrepancies between the results obtained 
with classical pharmacological tools, mainly HTR1B antagonists, and those obtained with HTR1B KO mice [186].

Another peculiarity of HTR1B protein is the characteristic of playing different roles depending on where they are located within the brain [129]; thus, the neuronal population in which these receptors are knocked out is another feature that may deeply influence the KO mice phenotype. Given this situation, in addition to the compensatory changes, the depletion of the HT1B receptor in the whole brain of the $\mathrm{KO}$ mice makes it difficult to define the relative contribution of these receptors in producing specific behavioral abnormalities. For example, it is impossible to discriminate the quite likely different if not opposite [11] role of the auto- or heteroreceptors in underlying a specific behavioral phenotype.

\section{Conditional KO models}

In addition to conventional KOs, alternative approaches can be used to manipulate the mouse genome in order to generate valid animal models. For example, conditional KOs allow investigation of a gene in a tissue-specific or time-controlled manner. Zhuang and collaborators, using the gene targeting technology, have developed a new strategy to re-express in $\mathrm{KO}$ the HTR1B missing protein in only specific brain areas or neuronal circuits where the receptor is normally expressed [186]. These rescue mice, together with inducible KO mice [164], may contribute in the future to identifying the neuronal circuits responsible for the different phenotypes observed in the HTR1B KO mice.

Finally, studies on HTR1B mRNA, which overexpresses itself in selected neuronal circuits using virally mediated gene transfer are worth mentioning [11, 36, 107]. This technique enables the study of the phenotypic impact of a gene product within selected anatomical regions avoiding, at the same time, possible developmental compensations characteristic of $\mathrm{KO}$ mice. Clark and coworkers have developed a virally mediated gene transfection strategy to express HTR1B in the dorsal raphe nucleus, demonstrating that the over-expression of this receptor in this area increases anxiety behavior specifically following stress exposure [36, 37]. A similar technique has also been used to increase the expression of the HTR1B in the nucleus accumbens (Nacc) [11, 107]. The over-expression of HTR1B in the Nacc sensitizes rats in the locomotorstimulating and rewarding proprieties of cocaine [107] and seems to intensify the rewarding as well as the negative properties of cocaine [11].

On the whole these techniques allow us to evaluate the role of the HTR1B protein in mediating a specific phenotype, assessed by using specific tests, that is possibly related to human symptoms of disease. Nonetheless, it is evident that certain features of human behavior cannot be reproduced in rodents (for example, suicide, concepts of self, self-reflection, consideration of others, or language [148]) and this may complicate the extrapolation of results obtained in animal tests to human symptoms. However, this is not the case in motivation, memory, and cognition for which there are many available behavioral tests that allowed us to evaluate the role of the HTR1B on different aspects of motivation [14, 23, 136-138] or memory and cognition [27, 28, 101, 118, 181, 182].

It is becoming clear that in the next few years the integration of results from animal models with new findings from humans (for example, ex vivo, neuroimaging, and genetic studies) will be needed to better understand how the HTR1B receptor affects various behaviors.

\section{Motivation}

\section{Definition}

Motivation is referred to as the set of reasons that determines one to engage in a particular behavior, and it is thought to be routed by the basic need to minimize physical pain and maximize pleasure. It is classically distinguished into appetitive vs consummatory behaviors [151]. Craig [43] figured out a four-phase shaped algorithm describing motivation:

1. Phase 1 is characterized by the "appetite" behavior, which is defined as the more variable and flexible, searching phase of a behavioral sequence.

2. Phase 2 is referred to as "consummatory," which is the stereotypic phase that begins when the object of the first phase is recognized and achieved.

3. Phase 3, the "aversion" phase.

4. Phase IV, the "freedom from stimulus" phase.

Ethologists provided figures further describing these behaviors: the "psycho-hydraulic" [97], the hierarchical model [168], and the theories of Beach [13] and Pfaus [120] are some examples. A complete and recent review on this topic can be found in Ball and Balthazart [8].

Implications for psychiatric disorders

Motivation can be started upon environmental or internal stimuli, and, consistent with this, it is not constant over time. The fluctuant adaptation to stimuli can be viewed as the result of the balance between neural networks that initiate and maintain motivational/hedonic affective and emotional states and networks that progressively promote their banishment [159]. This mechanism, when maintained as a good balance, promotes behaviors shaped to adapt to the environmental cues. If an imbalance occurs, an hyper-reward mechanism 
associated with the stimulus may facilitate compulsory seeking the stimulus [87]. This may be the hypothetical underlying mechanism associated with substance dependence. On the other hand, failed orchestration leading to the achievement of a constant and unresponsive retain of the neutral pole may facilitate a poor flexible hedonistic neutrality, resulting in a negative/depressive attitude; this may be reminding of some aspects of mood and schizophrenic disorders.

Functional neuroanatomy: focus on motivation

The brain structures that are associated with motivation have been classically identified as the mesolimbic system, the basal forebrain, and the associative areas of the cortex. The limbic system further provides the emotional and mnemonic computations to the output of these neuronal components. These structures compose an architecture whose detailed functional description is still incomplete. Nevertheless, there is evidence that [2]:

1. The mesolimbic system furnishes the dopaminergic drive to the motivational approach

2. The basal ganglia are involved in the association processes that are related to motivation

3. The hippocampus and the amygdala are essential in the storing and processing of memories and emotions

In particular, the basal ganglia, once thought to be primarily involved in the motor control, are also relevant for motivation; the relevance of the ventral pallidus for the reward and motivationally mediated functions has been convincingly demonstrated [157]. The striatum provides the principal inputs to the pallidus, while receiving and conveying information from the major afferent systems including the corticostriatal, the nigrostriatal, and the thalamostriatal structures. Moreover, afferents from the sensorimotor cortex terminate in the putamen (the internal part of the striatum) whilst association regions of the cortex terminate in the caudate nucleus (the external part of the striatum). The ventral striatum receives inputs from the hippocampus and amygdala (Fig. 2a). This way, motor, sensorimotor, affective. and mnemonic information are directed toward the striatum, processed in that structure and then directed toward the pallidus. The ventral part of the pallidus is the output source and directs the information toward the thalamus and to the cortex. This set of inputs and outputs likely concurs to compose the biological substrate that provides the flexibility required to adapt to stimuli and environmental cues, through the recruiting of memories and affective values, along with the applying of learning abilities and associative and cognitive skills. In addition, two other brain components are interlaced with the ventral pallidus: the nucleus accumbens (Nacc) and the dopaminergic input from the ventral tegmental area. Both of them project to the ventral pallidus through dopaminergic connections, and the mesolimbic system projects to the Nacc as well, so that the ventral pallidus receives a double input arising from the mesolimbic system directly and from the Nacc. Moreover, the Nacc projects back to the ventral tegmental area, thus forming a short feedback system (Fig. 2b).

\section{HTR1B and motivation}

Manipulation of the Nacc through the direct injection of GABAergic agonists or AMPA antagonists or opioid or cannabis agonists results in modified eating and drugseeking behaviors. This has been related to the disinhibition of the ventral pallidus caused by the inhibition of the Nacc [7, $29,82,133,134,166,180]$. This figure suggests a motivational impact refined by the Nacc (namely, the shell) on movement control. Notably, this disinhibition is not chaotic; it actually drives a set of behavioral patterns that are focused on eliciting pleasure, a goal that derives from the interplay between the mesolimbic system, the basal ganglia, the limbic system, and the cognitive and associative areas of the cortex [2]. Interestingly, HTR1B plays a pivotal role within these structures, being highly expressed in the basal ganglia [90]. Moreover, the serotonin system exerts inhibition of motivation directly from the raphe nucleus [10], thus suggesting that inhibiting the serotonergic system at the level of the Nacc or at the level of the raphe nucleus results in the same promotion of motivation, a redundant mechanism that likely enhances the flexibility of the system and enriches the cross-talking with other correlated systems.

Within the basal ganglia, the main input of activation is mediated by glutamate from the striatum and dopamine from the mesolimbic system; within this system, HTR1B plays a role as a pre-synaptic receptor with inhibiting activity [144], probably with certain differences from the dorsal to the

Fig. 2 A 3D representation of the central nervous system (CNS). The CNS is seen from the upper left side. The cerebral structures are represented in an anatomically coherent way in the picture on the left. The model has been opened out in the picture on the right: the limbic system has moved upward, the thalamus, the midbrain, the hypophysis and the basal ganglia are in their original positions, and the pons and the cerebellum have moved downward. The cortex, the midbrain, the hypophysis, the hypothalamus and the corpus callosus are rendered transparent in the picture on the left. The cortex and the corpus callosus have been deleted in the picture on the right. The model has been opened out in $\mathbf{a}$ and $\mathbf{b}$ to detail the neurological pathways in which HTR1B is primarily involved. a The motor system. Striatum inputs are represented along with the functionality of the ventral striatum in movement controls. Moreover, the nucleus accumbens (Nacc)-mediated limbic input is detailed. b The mesolimbic dopaminergic input to the ventral pallidus is both direct and mediated by the Nacc. Moreover, the Nacc projects back to the ventral tegmental area 


\section{a}

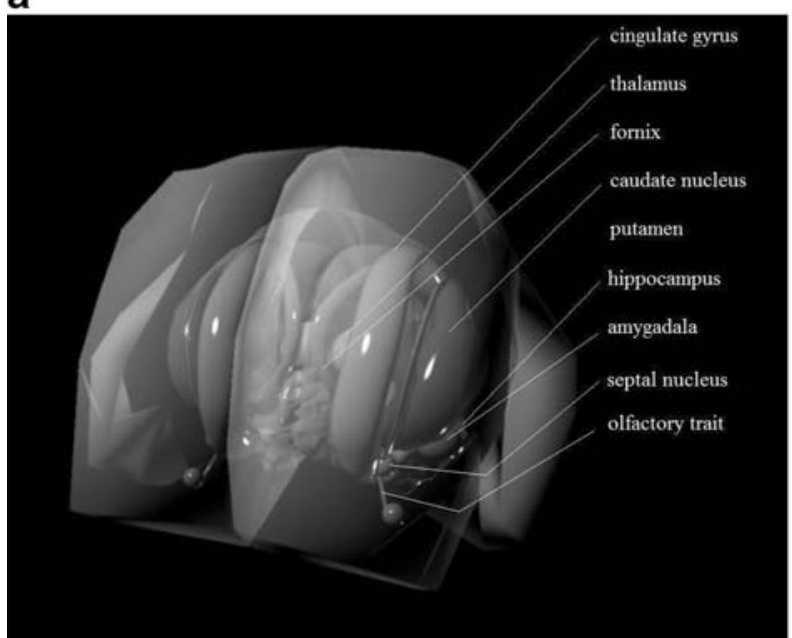

b

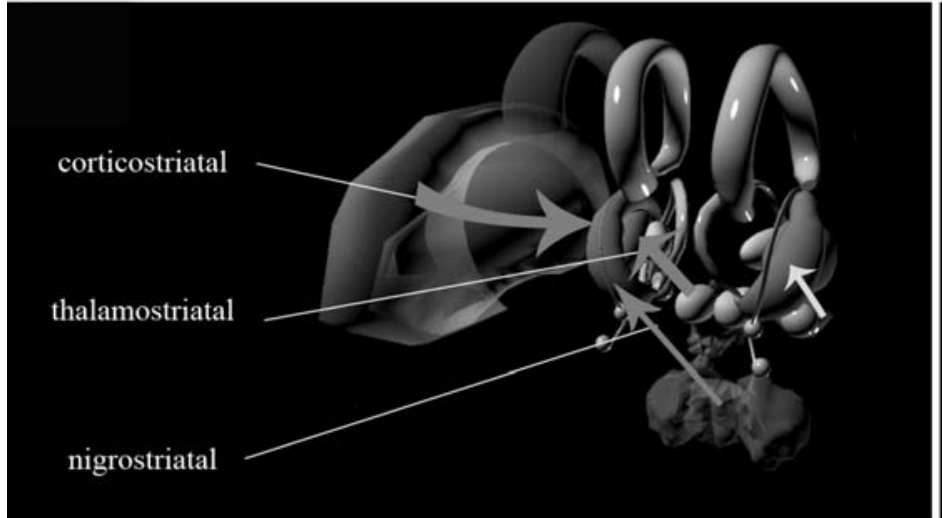

The striatum is the principal input brain structure receiving information from the cortex, from the thalamus and from the sub stantia nigra (three arrows on the left). Moreover, the ventral striatum receives inputs from the hippocampus and amygdala (small arrow on the right).
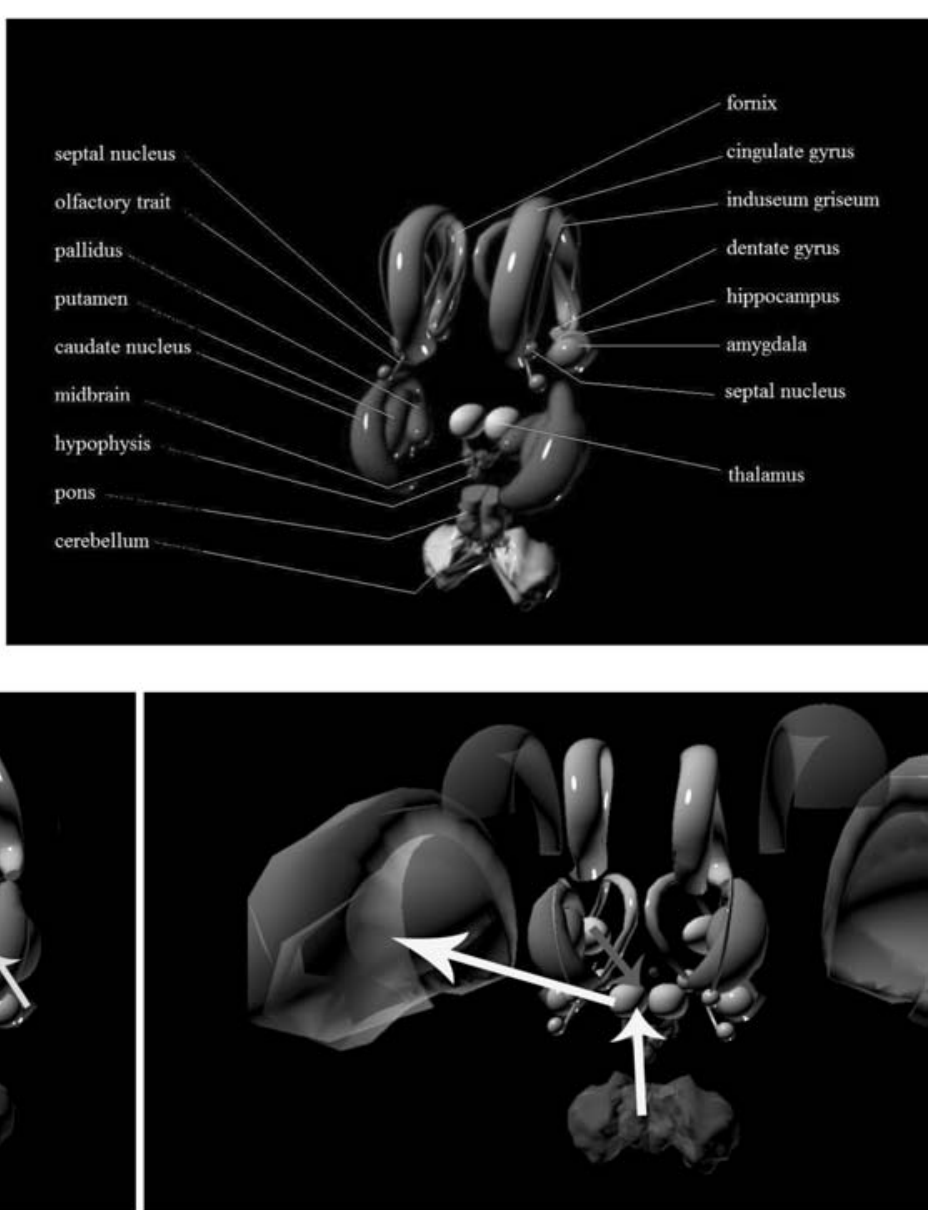

The ventral pallidum provides projections to the thalamus along with the substantia nigra. The thalamus then projects to the premotor and prefrontal cortices, giving rise to a circling formation which is enriched by the thalamic, limbic and basal ganglia computation.

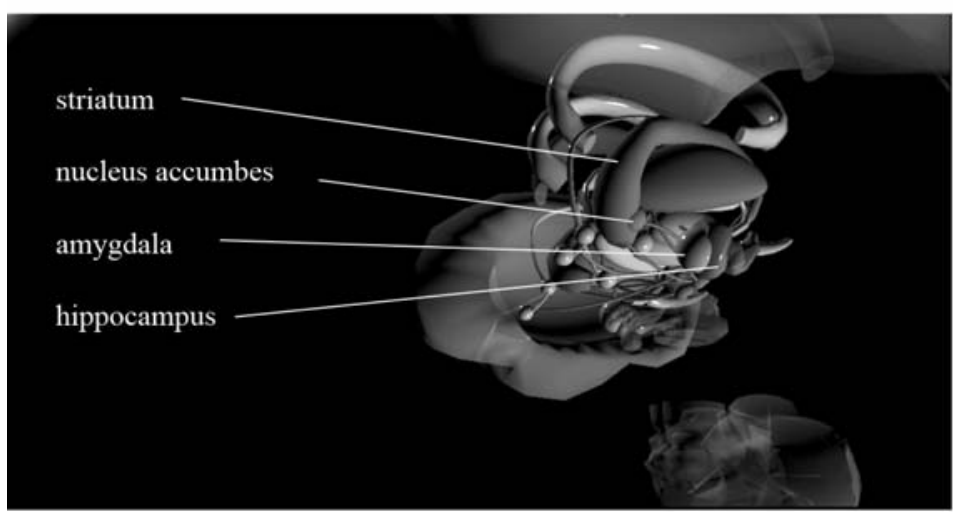

It has been proposed that the nucleus accumbens provides the ventral pallidum with the limbic information forming the "limbic motor integration" to the accumenbs-pallidal system. The nucleus acumens is part of the mesolimbic dopaminergic system, whose activation is thought to be pivotal to the motivational behavior. 


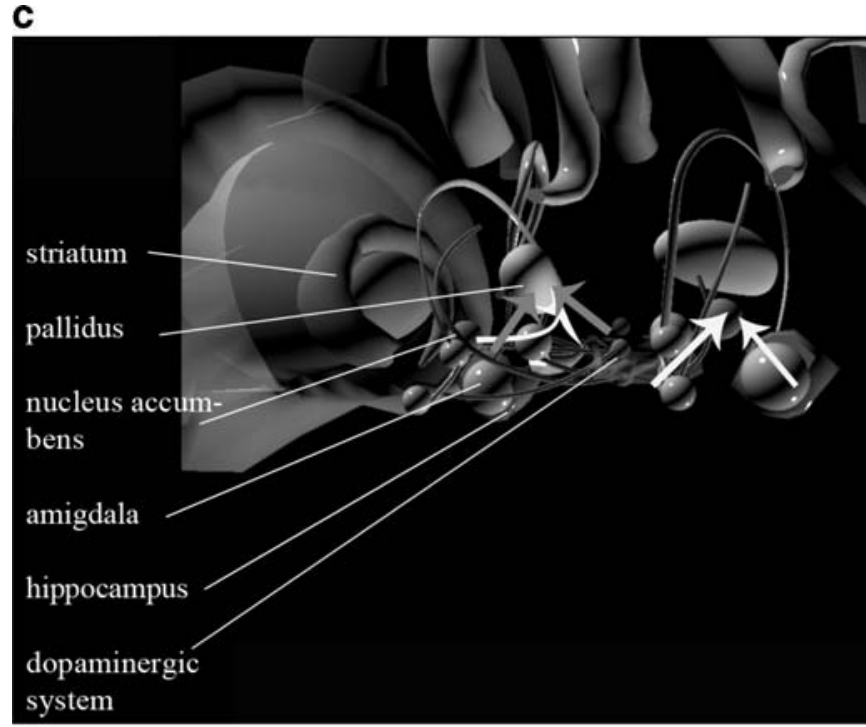

The mesolimbic system projects to the ventral pallidum (straight arrows) and to the Nacc (curved arrow) with dopaminergic efferences. At the same time, the Nacc projects to the ventral pallidum and mediates an inhibitory input to the structure (straight arrows). Moreover, the Nacc projects back to the ventral tegmental area (arrow not shown).

Fig. 2 (continued)

ventral striatum. It has been reported that the direct injection of HTR1B agonist CP-93,129 into the dorsal striatum resulted in changed dopaminergic and serotoninergic tones, only at a very high concentration [46]. The interplay between the deregulations of the monoaminergic systems after cocaine intake is characterized by a mediatory role exerted by serotonin with regard to the dopaminergic system [61], and a specific role of HTR1B is suggested; pretreatment with the RU24969-a HTR1B agonist-resulted in a leftward shift in cocaine self-administration [117], that is, in a reinforcement of the rewarding effect of cocaine, likely via serotonin-mediated enhancement of the dopamine concentration in the Nacc. Stimulation of the HTR1B leads to the downregulation of the serotonin tone in the striatum with a facilitator effect on the dopamine that results in higher, or more easily elicited, motivation for cocaine-seeking. Consistent with this figure, cocaine is able to increase the expression of HTR1B in the Nacc, likely eliciting the adaptation of the serotonergic-dopaminergic balance in the mesolimbic system $[75,113]$. In a recent experiment, Barot and colleagues [11] specifically enhanced the expression of HTR1B in the medium spiny neurons of the shell of the Nacc that project toward the ventral tegmental area and obtained a different response in transferred animals and controls; transferred animals showed an enhanced response to low doses of cocaine with respect to the control animals whilst they showed avoidance behavior at higher cocaine doses. This suggests that serotonin mediates both the rewarding and the negative properties of cocaine use via

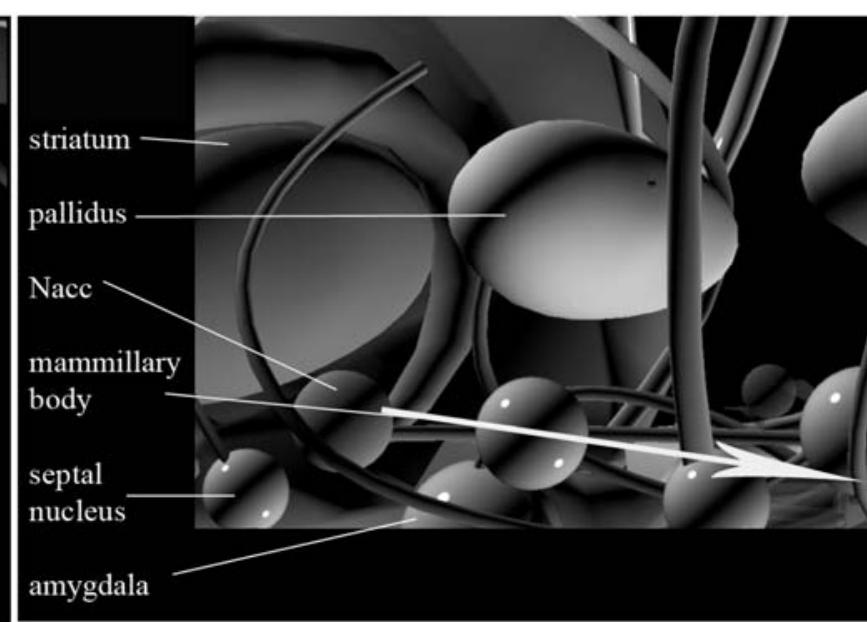

Manipulating the Nacc activity and inhibiting it results in an increase in "wanting" food but does not impact the "liking" food. Enhancing the expression of HTR1B in the shell of the Nacc results in an increased sensitivity to cocaine in animal models likely determined by a diminished inhibitory tone exerted by the serotonergic outputs from the Nacc to the ventral tegmental area (arrow).

the HTR1B receptors. This may be consistent with the different role exerted by HTR1B, excitatory toward serotonin tone in the raphe, and inhibitory in other parts of the brain. So far, enhancing the expression of HTR1B in the Nacc would result in diminished serotonin activity with regard to the dopaminergic system in the ventral tegmental area, thus promoting a behavior more sensitive to cocaine in animals. At higher doses, the excitatory role of HTR1B in the raphe nuclei would prevail and the effect of dopaminergic neurons that innervate the raphe nuclei and exert a tonic excitation [49] would also prevail. This influence may be mutual; the activation of the HTR1B via microinjection of specific agonists in the VTA resulted in enhanced dopamine release in the Nacc, both during cocaine administration and without cocaine administration, and the GABAergic tone in the VTA was found to be inversely correlated with the activity of the HTR1B. That is, the serotonergic activity in the VTA results in an inhibition of the dopaminergic output with regard to the Nacc [112], and consistently plays a permissive role in the development of cocaine sensitization [45, 60, 124]. Interestingly, it has been reported that the mediatory effect of serotonin over dopaminergic tone is more specifically associated with HTR1B than with HTR1A [112, 115, 116]. So far, serotonin has played an inhibitory role with regard to the dopaminergic tone, and this inhibition can be counteracted by the activation of the HTR1B in the Nacc. Being speculative, one can hypothesize that more efficacious HTR1B transmission might play a protective role in substance dependence disorders, as confirmed by indepen- 
dent studies [1, 33, 67, 98, 125, 126]. Consistent with this figure, Shippenberg and colleagues reported that the dopamine concentration in the Nacc was higher in HTR1B KO animals than in controls [153], and mice with both HTR1B knocked out showed a shorter latency period in meeting cocaine self-administration criteria [136]. Consistent with this, serotonin clearance was decreased in the event of HTR1B deletion [4]. Intriguingly, the antagonism as well as the absence of HTR1B resulted in higher 5HT concentration after paroxetine challenge in animal models [100]; acute stimulation leads to events that are opposite to those found in the event of chronic HTR1B inactivation. Some more consistent information is given by a recent experiment conducted by Faccidomo and colleagues [59]; the injection of a HTR1B agonist at the level of the raphe nuclei resulted in diminished aggressiveness, whilst enhanced aggressiveness was obtained after injection into the prefrontal cortex. Not only HTR1B has opposite behavioral effects in different parts of the brain, but it also shows different patterns of sensitiveness to enhanced serotonergic tone on a "neurogeographic" basis; a challenge with paroxetine was found to be associated with more clear cut differences in HTR1B expression in the ventral hippocampus than in the prefrontal cortex of animals [100], thus suggesting that the functions of HTR1B in the ventral hippocampus are more sensitive to the activities of antidepressants. Finally, animal models suggest a specific role of HTR1B in socially relevant behaviors such as rearing and grooming; the microinjection of HTR1B agonist into the prefrontal cortex of mice resulted in increased rearing and grooming behavior along with an increased aggressiveness after social instigation. Intriguingly, HTR1A agonist threat was associated with a similar effect on social aggressiveness, but a reversed effect on rearing and grooming [32]. That is, HTR1B stimulation in the prefrontal cortex of animals may lead to an enhanced behavioral reactivity to the external stimuli, which results in an association with both disruptive and social promoting activities, this being decided likely according to the cognitive interpretation the animal carries out of the environmental conditions. In addition to all these lines of evidence, serotonergic and dopaminergic tones are not the only mediators implied in these mechanisms. For example, the cholinergic activity is pivotal to cognitive flexibility, and, interestingly, cholinergic neurons express HTR1B heteroreceptors [57, 135].

\section{Memory \\ Definition}

Memory is the ability to store information and to use it upon internal or external request. Memory is classically classified as declarative memory (conscious memories) and non-declarative memory (unconscious memories). Declarative memories can be divided into episodic memories and semantic memories. Non-declarative memories are divided into several subgroups and these include classical conditioning, procedural memories, priming, and the working memory. The classical conditioning is referred to as the coupling of an unconditioned stimulus to a conditioned stimulus when they are repeatedly coupled over time; the procedural memories are those algorithms that operate at an automatically unconscious level, and priming is referred to as the event in which a particular object changes the response to the same object sequentially perceived. Working memory is the ability to keep in mind pieces of interlaced information according to the requirement of the moment. It is probable that different kinds of memories are stored in different neural networks, and in different formats as well [63]. Further, it is probable that memory consolidation and use is based upon molecular events located in the synaptic cleft. When a modification is achieved that resists interference, a trace memory is formed and can be used. These modifications can be short-lasting, based on the neuronal mediator release, and they are related to memory that lasts minutes or hours. Other memories last for a longer time, and they are supposedly based on long-lasting modification at the neurons, determined by changes in the expression profile of cells that lead to the molecular mechanisms of memory formation.

\section{Molecular mechanisms of memory formation}

The long-term potentiation (LTP) is considered to be the molecular basis of long-term memory; it is thought that external and internal events are represented in the brain as spatio-temporal patterns of neuronal activity that eventually determine the synaptic modifications that substantiate memory [18]. This model was formalized in the late 1940s by Hebb and Konoroski $[69,86]$ and it is referred to as the coincidence detection rule, in which the synapse linking two cells is strengthened when cells are active at the same time. This effect was named LTP in 1973 [17] and it has a number of properties that strengthens its basic role in mnemonic information; it is established quickly and lasts for a long time, it is associative in that it depends on the co-occurrence of presynaptic activity and postsynaptic depolarization, it occurs only at potentiated synapses, and predominantly in the hippocampus [161]. Glutamate is considered to be the mediator of the LPT formation. Moreover, modification in the formation of the dendritic spines probably plays a major role in determining the plastic changes that allow LTP formation [161]. It has been proposed that the translational control is basic to the formation of LTP, a notion that envisages new strategies in the treatment of memory dysfunction-related disorders [41, 104]. 
Functional neuroanatomy: focus on memory

Memories are the sum of many forms of information including visual, tactual, spatial, olfactory, associative, auditory stimuli. Consequently, the locations in which this information is stored in the brain varies according to the kind of stimuli, this being dependent on the well-known functional differentiation of brain areas. For example, visual information is stored in the inferotermporal cortex, whilst concurrent different components of the event (spatial, tactile, olfactory, and so on), are stored in other areas. Therefore, any particular event is recalled to memory by the activation of a network of neuronal components, each of them engaging a specific processing site [161]. The hippocampus may play a role in integrating the timing and amount of flow of this information, processing it through the input from the deep basal ganglia, limbic system and cerebral cortex among which mutual interconnections exist. Nevertheless, other brain regions have been claimed to be central in the processing of the other forms of memory: the kind of memory that allows retention of small pieces of information temporarily available during the ongoing execution of mental operations, referred to as working memory, is thought to be retained in the posterior parietal cortex $[132,174]$; the retaining and computation of this kind of information is essential to learning abilities and abstract thinking. Other forms of memory, such as the instrumental memory, are thought to be retained in other parts of the brain [72].

Functional neuroanatomy: episodic memory

The neuronal brain structure functionally related to the episodic memory is the medial temporal lobe, which includes the parahippocampal gyrus, the presubiculum, the subiculum, and the hippocampus. Other brain structures functionally related to this kind of memory are the anterior thalamic nucleus, the mammillary body, the fornix, and the prefrontal cortex. The flow of information coming from the activation of neural networks comes from the activation of senses and associative regions of the brain upon simple stimuli such as visual, auditory, tactile, and olfactory, but emotions and thoughts as well. Let us say that all these inputs are referred to the experience of having a dinner. This flow of information is conveyed in the parahippocampal region and subsequently to the hippocampus. Then, afterward, the information is processed in the dentate gyrus and transferred to the $\mathrm{CA} 3$ region, which corresponds to a specific zone in the hippocampal cortex. In that region, episodic memories are thought to be retrieved so that a similar dinner that might happen in the near future will be associated with the one we are remembering on the basis of the similar neuronal pattern of activation that is carried to the CA3 region in the hippocampus. Moreover, once reactivated, the information stored in that part of the brain can elicit the emergence of all the correlated neuronal paths, so that a scent is able to recall to memory a whole scene. The hippocampus is not the final destination of a memory trace; when a process referred to as consolidation occurs, the information is thought to be moved from the hippocampal-cortex networks to the cortical-cortex ones. This event is crucial to the cognitive flexibility in order to face internal and external requests; memories are then not frozen in the hippocampus and they can be changed following the needs determined by the environment. While information is temporarily stored in the hippocampus (temporarily may mean years or minutes), the frontal lobes are believed to be primarily involved in the acquisition and temporal encoding of memory traces, as well as in their active retrieval in the absence of contextual stimulus [81, 119, 155], with a specific pattern of lateralization that depends on the kind of stimulus that is processed [25, 177]. Moreover, the involvement of the frontal and the posterior parietal cortex activities are thought to be associated with the ability to direct attention toward a certain focus, thus selecting the kind and amount of information that should be stored in the brain, on the basis of the superior associative activity of the brain $[132,174]$. Consistent with this, deregulation of these mechanisms is associated with impaired memory, or with the production of false memories, or with a biased processing of memories so that, for example, negative events are preferentially stored and recalled, which may be one of the disrupted neural networks that underpins depressive disorders.

Functional neuroanatomy: semantic memory

Facts and concepts not related to any specific memory are the objects of the semantic memory. Examples are the ability to name a thing, to recall the common color of an object, to understand single words. There is evidence that the semantic memory is localized in the frontal cortex and in the anterior and inferolateral temporal lobes [9, 95, 123]. It is considered to be independent from the episodic memory, and, consistently, semantic and episodic memories decline independently of one another in Alzheimer's disease [65].

Functional neuroanatomy: classical conditioning and working memory

The classical conditioning is referred to as the event of the coupling between a unconditioned and a conditioned stimulus after they have been paired together repeatedly. It can be associated with autonomic responses, in the case of fear, for example, or with motor responses. The amygdala and the basolateral limbic system, which includes the 
dorsomedial thalamic nuclei, the area subcallosa, and the stria terminalis, are relevant for autonomic conditioning, whilst the cerebellum is relevant for motor conditioning. Working memory is classically associated with the functions of the prefrontal cortex, but virtually every part of the cortex is engaged in the processing of information, depending on which task is being performed. Interestingly, spatially related information is preferably processed by the regions of the right side, whilst phonological tasks are computed in the left side of the brain. Nonetheless, the most difficult tasks activate all the brain regions in a fashion that is independent of the kind of stimulus [109].

\section{Implications for psychiatric disorders}

Memory- or mnemonic-related functions are impaired during psychiatric sufferance. In particular, depressive disorder was found to be associated with impaired function of the hippocampus, the parahippocampal gyrus, the prefrontal cortex, the cingulate cortex, and the parietal regions [147, 179]; this deregulation was found to be associated with a higher rate of false memories, which, quite interestingly, often show a prominent negative affective meaning [64, 184]. This may be one of the biological events that enhances the risk of experiencing a depressive episode. Interestingly, antidepressant treatment proved to be effective in restoring normal memory activity [73]. Memory function was found to be impaired in bipolar patients and their relatives [20, 83, 128] and in schizophrenic patients as well [71, 91, 131]. Moreover, working memory and executive functions have been claimed to be promising endophenotypes through which early signs of psychotic disease can be detected [12, 16]. Finally, the conditioning events related to the activation of the amygdala have been associated with psychiatric disorders in a consistent number of reports (reviewed in Quirk and Gehlert [127]).

\section{HTR1B and memory}

The relevance of HTR1B in memory tasks is reported by several lines of evidence; activation of HTR1B results in an impaired spatial learning task [26], and, interestingly, the stimulation of HTR1B is associated with neophobic reactions when exploring unknown objects [26]. This latter piece of evidence was not replicated in HTR1B KO animals [101], even though HTR1B KO mice showed enhanced locomotor behavior in an enriched environment compared with WT animals. This was commented on as a possible effect of the major impulsivity that is classically associated with the deletion of the serotonin receptor $1 \mathrm{~B}$, and a parallelism with the syndrome of "overattention" that is found in schizophrenia was suggested [101]. Interestingly, in the afore-mentioned study HTR1B KO mice did not show habituation to the environment, which was interpreted as an impairment of memory functions. In 2003, Buhot and colleagues confirmed that HTR1B KO animals presented with higher flexibility in the acquisition of spatial preference memory task, and a decreased ability in a working memory task with intermediate and long delays. This is suggestive of an impairment in the ability to keep memories of functionally associated events in order to use them for a specific purpose, and to facilitate the flexibility of cognitive ability, at least for simple tasks [27]. These events are in line with the notion that different kinds of memories are stored in specific neural networks and with the aforementioned different role played by HTR1B in different parts of the brain. In particular, the working memory tasks involve an efficient communication between the limbic structures and the prefrontal cortex, whilst the spatial memory is likely more related to the interplay between areas associated with visual stimuli, the hippocampus and postero-parietal cortices. In these networks, the role of HTR1B is likely associated with the impact of the serotoninergically mediated glutamatergic input that arises from the raphe nuclei to the cortex and of the cholinergic input from the cholinergic structures in the basal forebrain to the cortex [27]. Thus, the absence of HTR1B results in a lack of inhibition in the networks that regulate the information flow that is necessary for the cognitive computation related to spatial navigation. Interestingly, it was reported that the difference between WT and HTR1B $\mathrm{KO}$ mice is more evident when animals are challenged with difficult tasks that require higher cognitive flexibility [181, 182]. This can be related to the fact that HTR1B activity results in a down-regulation of the cholinergic tone in the hippocampus and in enhanced cholinergic tone in the frontal cortex [31, 40]. Moreover, HTR1B are expressed on terminals of retinal ganglion cells in the superior colliculus [22] where they control visual attentional processes with an inhibitory role [21]; uninhibited visual activity may be intuitively related to enhanced ability in spatial tests. Another relevant hint is provided by the evidence that HTR1B KO animals show an increased pattern of prepulse inhibition compared with WT animals. This may be dependent on the higher cholinergic tone in the cortex associated with HTR1B deactivation, which would provide the animal with a keener-and less flexibleattention ability with regard to stimuli [54]. This may have a very relevant impact on the pathophysiology related to the obsessive compulsive disorder [150], even though recent experiments on animals suggest that the hyper-reactivity of mice deprived of the HTR1B may be more related to a deregulated startle reactivity [50], a behavior closer to impulsivity in our opinion. Consistent with this, it has been suggested that impulsivity and not memory is mainly impaired in HTR1B KO animals [118]. 


\section{Genetic association studies}

The mechanisms described above suggest that the variation in the activity of the HTR1B should be associated with an impact on human behavior, including psychiatric phenotypes; impaired orchestration of motivation and memory may likely be associated with a set of well-known clusters of symptoms shown by psychiatric patients, by including diagnoses as diverse as substance abuse disorders, mood disorders, anxiety disorders, and the psychotic spectrum. Nonetheless, the genetic association studies conducted so far provided poor evidence for this statement; moreover, no specific genetic association study involving the HTR1B has been conducted on memory and motivation so far. The most relevant results are reported in Tables 3, 4, 5, 6, 7 .

\section{Substance-related disorders}

Overall, the most consistent findings are reported for substance abuse disorders. In 1998, Lappalainen and colleagues [89] analyzed two variations located in the HTR1B, namely the G861C and a closely linked shorttandem repeat locus, D6S284. Authors collected a large sample of 640 Finnish subjects, including 166 alcoholic criminal offenders, 261 relatives, and 213 healthy controls. Further, they analyzed the same set of variations in a large multigenerational family derived from a Southwestern American Indian tribe $(n=418)$ with a high rate of alcoholism. The design of the study is of particular interest because it combines the analysis of cases and controls with the analysis of the pattern of heredity of those mutations and their correlation with the risk of alcoholism. Moreover, the sample size is one of the largest ever investigated in this field. Nonetheless, the strength of the association was weak for alcoholism alone $(0.05<P<0.06)$. Interestingly, a stronger association was found when antisocial personality disorder was considered in association with alcoholism $(P=$ 0.005). The investigation in the American Indian tribe confirmed these trends $(P=0.01)$. Despite the drawbacks that characterize the investigation (for example, incomplete gene coverage), this finding first suggests that a variation in the genetic framework of HTR1B leads to a pervasive pathological attitude that results in a personality disorder in association with a tendency to consume alcohol, rather than in alcoholism alone. This difference is quite interesting as it could underline a specific regulation that separates Axis I from Axis II disorders. Unfortunately, knowledge in this field is still too incomplete to allow any figure to be drawn other than a highly speculative one. The findings reported by Lappalainen and colleagues were further enriched by the observation that the variation found to be associated with alcoholism in antisocial personality disorder was actually associated with a different expression of HTR1B in the prefrontal cortex of subjects, that is, the $\mathrm{G}$ allele at 861 associated with $20 \%$ less HTR1B expression compared with the $\mathrm{C}$ allele [77]. This is highly consistent with the evidence reported from animal models that demonstrated that the stimulation of HTR1B in the prefrontal cortices of mice resulted in different patterns of aggressiveness. The same study [77] failed to demonstrate a difference between suicidal behavior or alcoholism-related disorders; this may be related to the small sample sizes that were obtained after classification in the different diagnostic clusters.

\section{Obsessive compulsive disorder}

The G861C variation has been quite extensively analyzed in OCD patients as well, and reported quite consistent results as detailed in Table 7. In particular, the G allele, which was found to be associated with a lower expression profile in the PFC of subjects, was found to be at risk of obsessive symptoms, or to be associated with a worse presentation of symptoms. The conflicting results $[48,70]$ may be associated with underpowered samples [48] or with the analysis in non-Caucasian samples [70]; diverse ethnicities may show profound differences in the genetic predisposition to psychiatric disorders, the case of the well-known long/short variation in the promoter of the serotonin transporter gene being an emblematic example in that there is some evidence that it behaves within opposite paths in Caucasian vs Asian samples [158].

\section{Psychosis and bipolar disorders}

Despite the fact that HTR1B mRNA was found to be differently represented (upregulated) in the brains of schizophrenic and bipolar patients compared with controls [96], the genetic association studies that have been performed in these populations did not cast conclusive results. The most relevant studies performed on schizophrenic samples are reported in Table 5. The absence of results is quite surprising in that it has been demonstrated that variations in the activity of the HTR1B result in altered measures of central processing information in animals, that is, significant variations in startle reactivity, habituation, and prepulse inhibition [53, 54]. In particular, HTR1B is thought to decrease prepulse inhibition and habituation, whilst HTR1A showed opposite effects in mice [56]. These dimensions have been shown to be deficient in schizophrenic patients, but a correlation with the investigated variations located in the HTR1B and the schizophrenic phenotype did not sustain this relevance.

Suicidal behavior

Aggressiveness and impulsiveness are characteristic phenotypes derived from the absence of HTR1B in animal 
models. This evidence attracted the attention of researchers interested in the genetic background that predisposes to suicidal acts as far as a high degree of impulsiveness and aggressiveness are associated with that behavior. Unfortunately, although extensively investigated, the association between HTR1B and suicidal behavior was not demonstrated as reported in Table 3. The reasons for this inconsistent evidence may be associated with the underpowered samples that characterize most of the investigation. Moreover, the absence of a complete coverage of genetic variations is more often the rule rather than the exception in the literature, and the lack of investigation of the molecular path associated with the activation of HTR1B further impairs the possibility of accounting for the impact of HTR1B on psychiatric sufferance. These issues, along with other methodological suggestions, have been discussed in more detail in other papers we have published on the topic $[51,149]$.

\section{Conclusion}

The molecular and neuroanatomical mechanisms that sustain the relevance of HTR1B with regard to psychiatric sufferance have been reviewed in this paper in the light of two brain functions as relevant as motivation and memory. The experiments conducted on animal models seem to extensively sustain the pivotal role of HTR1B in the functioning of high level brain functions, but genetic association analyses in human samples could confirm this association only for obsessive compulsive disorder and substance-related disorders, especially in the presence of personality disorders. In particular, an impaired balance in HTR1B associated with the presence of the G allele at the G861C variation proved to be functionally relevant and associated with obsessive compulsive disorders as well as with alcohol dependence. The lower HTR1B expression in the PFC, which was found to be associated with the G allele at G861C may be the cause of a dopaminergic imbalance in the PFC cortex that would result in complex imbalances responsible for those psychiatric deregulations. Intriguingly, this seem to be fairly specific: schizophrenic and bipolar disorders were consistently found not to be associated with this variation, and nor was suicide behavior. It could be said that greater anxiety develops from the disrupted function of HTR1B, which is driven toward a varied set of compulsions being activated in the context of personality disorder, substance use disorder or obsessive compulsive disorder. Although suggestive, this figure seems to be only partially supported by genetic association analyses in that not all the studies confirmed the significant association results. This may depend on the poor complexity of the approach that characterizes most investigations, some of the more relevant aspects of this incompleteness are:

1. Psychiatric phenotypes are uneasily reduced to a biological dichotomic variable such as single genetic variations. The search for associations between genetic variants and psychological dimensions may provide better results. It has been recently reported that a haplotype in the HTR1B gene (rs11568817, rs130058, rs6296, rs6297, rs13212041) impacts on the feeling of anger in male healthy volunteers, with the low expression haplotype being associated with greater anger and hostility [39].

2. It may be hypothesized that a set of biological events might adapt to the functional variations that are genetically driven and recompose the homeostasis or, at least, a kind of allostatic equilibrium. This allostasis produces a biological load that may actually be associated with the risk of experiencing psychiatric sufferance, but that would result in a fully diagnosed psychiatric episode only at its very extreme poles. In other words, the co-occurrence of other events, which may be both biological and psychological in nature, are likely needed to turn the genetic liability associated with HTR1B variation into a full episode of disease as depicted in DSM IV. Thus, the investigations meant to unravel the associations between the genetic background and behavioral experience should take into strict and detailed account the psychological and biological events that characterize, and stratify, the samples, both cases and controls. The need to include in the analysis the psychological events in cases and controls should characterize the next investigations in this field, along with a more complex molecular approach to the matter. For example, other mutations should be taken into account, ranging from the complete coverage of the HTR1B gene, through a tag approach, to analysis of the variations that are detailed in this paper.

3. Copy number variations, epigenetic controls, epistasis between genes involved in the same molecular mechanisms as HTR1B, the analysis of the impact of micro RNAs on the expression of HTR1B and the investigation of possible mRNA editing controls should be scheduled in the next investigations. For example, there is evidence that the p11 controls the activity of HTR1B $[167,185]$, so that every functional genetic variation located in the HTR1B could be regulated and counteracted in its functional imbalance by the activity of such a protein.

4. There is an interaction between HTR1B and HTR2B [80], and between HTR1B and aging as well [28, 154]. Moreover, the role with regard to nociception of HTR1B has been extensively investigated $[15,84,94$, $111,139]$, and a modulation of psychiatric disruption in 
terms of an altered nociceptive signal computation could be hypothesized.

The main result of this review is that the gap between the physiology that sustains the relevance of HTR1B in psychiatric-related events and reactions and the poor and sparse evidence of human samples, may be bridged by a far more complex and deep knowledge of the molecular mechanisms associated with this receptor and of its gene, in specific parts of the brain.

Acknowledgements Funding Information: we acknowledge the Fondazione del Monte di Bologna e Ravenna for having provided a grant. Prot. $915 \mathrm{bis} / 2008$.

Conflict of interest None.

\section{References}

1. Acosta JI, Boynton FA, Kirschner KF, Neisewander JL (2005) Stimulation of 5-HT1B receptors decreases cocaine- and sucrose-seeking behavior. Pharmacol Biochem Behav 80:297307

2. Alcaro A, Huber R, Panksepp J (2007) Behavioral functions of the mesolimbic dopaminergic system: an affective neuroethological perspective. Brain Res Rev 56:283-321

3. Anthony JP, Sexton TJ, Neumaier JF (2000) Antidepressantinduced regulation of 5-HT(1b) mRNA in rat dorsal raphe nucleus reverses rapidly after drug discontinuation. J Neurosci Res 61:8287

4. Ase AR, Reader TA, Hen R, Riad M, Descarries L (2001) Regional changes in density of serotonin transporter in the brain of 5-HT1A and 5-HT1B knockout mice, and of serotonin innervation in the 5-HT1B knockout. J Neurochem 78:619-630

5. Ase AR, Senecal J, Reader TA, Hen R, Descarries L (2002) Decreased G-protein coupling of serotonin 5-HT(1A) receptors in the brain of 5-HT(1B) knockout mouse. Neuropharmacology 42:941-949

6. Ase AR, Reader TA, Hen R, Descarries L (2008) Regionally selective changes in neurotransmitter receptors in the brain of the 5-HT1B knockout mouse. J Chem Neuroanat 35:356-363

7. Bakshi VP, Kelley AE (1993) Feeding induced by opioid stimulation of the ventral striatum: role of opiate receptor subtypes. J Pharmacol Exp Ther 265:1253-1260

8. Ball GF, Balthazart J (2008) How useful is the appetitive and consummatory distinction for our understanding of the neuroendocrine control of sexual behavior? Horm Behav 53:307-311; author reply 315-318

9. Balota DA, Watson JM, Duchek JM, Ferraro FR (1999) Crossmodal semantic and homograph priming in healthy young, healthy old, and in Alzheimer's disease individuals. J Int Neuropsychol Soc 5:626-640

10. Bannai M, Fish EW, Faccidomo S, Miczek KA (2007) Antiaggressive effects of agonists at 5-HT1B receptors in the dorsal raphe nucleus of mice. Psychopharmacology (Berl) 193:295304

11. Barot SK, Ferguson SM, Neumaier JF (2007) 5-HT(1B) receptors in nucleus accumbens efferents enhance both rewarding and aversive effects of cocaine. Eur J Neurosci 25:3125-3131

12. Barrantes-Vidal N, Aguilera M, Campanera S, Fatjo-Vilas M, Guitart M, Miret S, Valero S, Fananas L (2007) Working memory in siblings of schizophrenia patients. Schizophr Res 95:70-75

13. Beach FA (1956) Characteristics of masculine "sex drive". Neb Symp Motiv 4:1-32

14. Bechtholt AJ, Smith K, Gaughan S, Lucki I (2008) Sucrose intake and fasting glucose levels in 5-HT(1A) and 5-HT(1B) receptor mutant mice. Physiol Behav 93:659-665

15. Berrocoso E, Rojas-Corrales MO, Mico JA (2006) Differential role of 5-HT1A and 5-HT1B receptors on the antinociceptive and antidepressant effect of tramadol in mice. Psychopharmacology (Berl) 188:111-118

16. Birkett P, Sigmundsson T, Sharma T, Toulopoulou T, Griffiths TD, Reveley A, Murray R (2008) Executive function and genetic predisposition to schizophrenia - the Maudsley family study. Am J Med Genet B Neuropsychiatr Genet 147:285-293

17. Bliss TV, Lomo T (1973) Long-lasting potentiation of synaptic transmission in the dentate area of the anaesthetized rabbit following stimulation of the perforant path. J Physiol 232:331356

18. Bliss TV, Collingridge GL (1993) A synaptic model of memory: long-term potentiation in the hippocampus. Nature 361:31-39

19. Boe R, Gjertsen BT, Doskeland SO, Vintermyr OK (1995) 8Chloro-cAMP induces apoptotic cell death in a human mammary carcinoma cell (MCF-7) line. Br J Cancer 72:1151-1159

20. Bora E, Vahip S, Akdeniz F, Ilerisoy H, Aldemir E, Alkan M (2008) Executive and verbal working memory dysfunction in first-degree relatives of patients with bipolar disorder. Psychiatry Res 161:318-324

21. Boulenguez P, Foreman N, Chauveau J, Segu L, Buhot MC (1995) Distractibility and locomotor activity in rat following intra-collicular injection of a serotonin 1B-1D agonist. Behav Brain Res 67:229-239

22. Boulenguez P, Pinard R, Segu L (1996) Subcellular localization of 5-HT1B binding sites in the stratum griseum superficiale of the rat superior colliculus: an electron microscopic quantitative autoradiographic study. Synapse 24:203-212

23. Bouwknecht JA, Hijzen TH, van der Gugten J, Maes RA, Hen R, Olivier B (2001) Absence of 5-HT(1B) receptors is associated with impaired impulse control in male 5-HT(1B) knockout mice. Biol Psychiatry 49:557-568

24. Bramley JR, Sollars PJ, Pickard GE, Dudek FE (2005) 5-HT1B receptor-mediated presynaptic inhibition of GABA release in the suprachiasmatic nucleus. J Neurophysiol 93:3157-3164

25. Brewer JB, Zhao Z, Desmond JE, Glover GH, Gabrieli JD (1998) Making memories: brain activity that predicts how well visual experience will be remembered. Science 281:1185-1187

26. Buhot MC, Patra SK, Naili S (1995) Spatial memory deficits following stimulation of hippocampal 5-HT1B receptors in the rat. Eur J Pharmacol 285:221-228

27. Buhot MC, Wolff M, Benhassine N, Costet P, Hen R, Segu L (2003) Spatial learning in the 5-HT1B receptor knockout mouse: selective facilitation/impairment depending on the cognitive demand. Learn Mem 10:466-477

28. Buhot MC, Wolff M, Savova M, Malleret G, Hen R, Segu L (2003) Protective effect of 5-HT1B receptor gene deletion on the age-related decline in spatial learning abilities in mice. Behav Brain Res 142:135-142

29. Caille S, Parsons LH (2006) Cannabinoid modulation of opiate reinforcement through the ventral striatopallidal pathway. Neuropsychopharmacology 31:804-813

30. Camarena B, Aguilar A, Loyzaga C, Nicolini H (2004) A family-based association study of the 5-HT-1Dbeta receptor gene in obsessive-compulsive disorder. Int J Neuropsychopharmacol 7:49-53

31. Cassel JC, Jeltsch H, Neufang B, Lauth D, Szabo B, Jackisch R (1995) Downregulation of muscarinic- and 5-HT1B-mediated 
modulation of $[3 \mathrm{H}]$ acetylcholine release in hippocampal slices of rats with fimbria-fornix lesions and intrahippocampal grafts of septal origin. Brain Res 704:153-166

32. Centenaro LA, Vieira K, Zimmermann N, Miczek KA, Lucion $\mathrm{AB}$, de Almeida RM (2008) Social instigation and aggressive behavior in mice: role of 5-HT1A and 5-HT1B receptors in the prefrontal cortex. Psychopharmacology (Berl) 201:237-248

33. Cervo L, Rozio M, Ekalle-Soppo CB, Carnovali F, Santangelo E, Samanin R (2002) Stimulation of serotonin1B receptors induces conditioned place aversion and facilitates cocaine place conditioning in rats. Psychopharmacology (Berl) 163:142-150

34. Chenu F, David DJ, Leroux-Nicollet I, Le Maitre E, Gardier AM, Bourin M (2008) Serotonin1B heteroreceptor activation induces an antidepressant-like effect in mice with an alteration of the serotonergic system. J Psychiatry Neurosci 33:541-550

35. Cigler T, LaForge KS, McHugh PF, Kapadia SU, Leal SM, Kreek MJ (2001) Novel and previously reported singlenucleotide polymorphisms in the human 5-HT(1B) receptor gene: no association with cocaine or alcohol abuse or dependence. Am J Med Genet 105:489-497

36. Clark MS, Sexton TJ, McClain M, Root D, Kohen R, Neumaier JF (2002) Overexpression of 5-HT1B receptor in dorsal raphe nucleus using Herpes Simplex Virus gene transfer increases anxiety behavior after inescapable stress. J Neurosci 22:45504562

37. Clark MS, Vincow ES, Sexton TJ, Neumaier JF (2004) Increased expression of 5-HT1B receptor in dorsal raphe nucleus decreases fear-potentiated startle in a stress dependent manner. Brain Res 1007:86-97

38. Clifton PG, Lee MD, Somerville EM, Kennett GA, Dourish CT (2003) 5-HT1B receptor knockout mice show a compensatory reduction in 5-HT2C receptor function. Eur J Neurosci 17:185190

39. Conner TS, Jensen KP, Tennen H, Furneaux HM, Kranzler HR, Covault J (2009) Functional polymorphisms in the serotonin 1B receptor gene (HTR1B) predict self-reported anger and hostility among young men. Am J Med Genet B Neuropsychiatr Genet doi:10.1002/ajmg.b.30955

40. Consolo S, Arnaboldi S, Ramponi S, Nannini L, Ladinsky H, Baldi G (1996) Endogenous serotonin facilitates in vivo acetylcholine release in rat frontal cortex through 5-HT 1B receptors. J Pharmacol Exp Ther 277:823-830

41. Costa-Mattioli M, Sossin WS, Klann E, Sonenberg N (2009) Translational control of long-lasting synaptic plasticity and memory. Neuron 61:10-26

42. Crabbe JC, Phillips TJ, Feller DJ, Hen R, Wenger CD, Lessov CN, Schafer GL (1996) Elevated alcohol consumption in null mutant mice lacking 5-HT1B serotonin receptors. Nat Genet 14:98-101

43. Craig W (1917) Appetites and aversions as constituents of instincts. Proc Natl Acad Sci U S A 3:685-688

44. Cross TG, Scheel-Toellner D, Henriquez NV, Deacon E, Salmon M, Lord JM (2000) Serine/threonine protein kinases and apoptosis. Exp Cell Res 256:34-41

45. David V, Segu L, Buhot MC, Ichaye M, Cazala P (2004) Rewarding effects elicited by cocaine microinjections into the ventral tegmental area of C57BL/6 mice: involvement of dopamine D1 and serotonin1B receptors. Psychopharmacology (Berl) 174:367-375

46. De Groote L, Olivier B, Westenberg HG (2003) Role of 5-HT1B receptors in the regulation of extracellular serotonin and dopamine in the dorsal striatum of mice. Eur J Pharmacol 476:71-77

47. Dent P, Campbell DG, Hubbard MJ, Cohen P (1989) Multisite phosphorylation of the glycogen-binding subunit of protein phosphatase-1G by cyclic AMP-dependent protein kinase and glycogen synthase kinase-3. FEBS Lett 248:67-72
48. Di Bella D, Cavallini MC, Bellodi L (2002) No association between obsessive-compulsive disorder and the 5-HT(1Dbeta) receptor gene. Am J Psychiatry 159:1783-1785

49. Di Giovanni G, Di Matteo V, Pierucci M, Esposito E (2008) Serotonin-dopamine interaction: electrophysiological evidence. Prog Brain Res 172:45-71

50. Dirks A, Pattij T, Bouwknecht JA, Westphal TT, Hijzen TH, Groenink L, van der Gugten J, Oosting RS, Hen R, Geyer MA, Olivier B (2001) 5-HT1B receptor knockout, but not 5-HT1A receptor knockout mice, show reduced startle reactivity and footshock-induced sensitization, as measured with the acoustic startle response. Behav Brain Res 118:169-178

51. Drago A, De Ronchi D, Serretti A (2007) Incomplete coverage of candidate genes: a poorly considered bias. Curr Genomics $8: 476-483$

52. Duan S, Yin H, Chen W, Xing Q, Chen Q, Guo T, Gao J, Li X, Gao R, Liu Z, Gu N, Feng G, He L (2005) No association between the serotonin $1 \mathrm{~B}$ receptor gene and schizophrenia in a case-control and family-based association study. Neurosci Lett 376:93-97

53. Dulawa SC, Hen R, Scearce-Levie K, Geyer MA (1997) Serotonin1B receptor modulation of startle reactivity, habituation, and prepulse inhibition in wild-type and serotonin1B knockout mice. Psychopharmacology (Berl) 132:125-134

54. Dulawa SC, Hen R, Scearce-Levie K, Geyer MA (1998) 5-HT1B receptor modulation of prepulse inhibition: recent findings in wild-type and 5-HT1B knockout mice. Ann N Y Acad Sci 861:79-84

55. Dulawa SC, Scearce-Levie KA, Hen R, Geyer MA (2000) Serotonin releasers increase prepulse inhibition in serotonin $1 \mathrm{~B}$ knockout mice. Psychopharmacology (Berl) 149:306-312

56. Dulawa SC, Gross C, Stark KL, Hen R, Geyer MA (2000) Knockout mice reveal opposite roles for serotonin $1 \mathrm{~A}$ and $1 \mathrm{~B}$ receptors in prepulse inhibition. Neuropsychopharmacology 22:650-659

57. Eriksson TM, Madjid N, Elvander-Tottie E, Stiedl O, Svenningsson P, Ogren SO (2008) Blockade of 5-HT 1B receptors facilitates contextual aversive learning in mice by disinhibition of cholinergic and glutamatergic neurotransmission. Neuropharmacology 54:1041-1050

58. Evrard A, Laporte AM, Chastanet M, Hen R, Hamon M, Adrien J (1999) 5-HT1A and 5-HT1B receptors control the firing of serotoninergic neurons in the dorsal raphe nucleus of the mouse: studies in 5-HT1B knock-out mice. Eur J Neurosci 11:3823-3831

59. Faccidomo S, Bannai M, Miczek KA (2008) Escalated aggression after alcohol drinking in male mice: dorsal raphe and prefrontal cortex serotonin and 5-HT(1B) receptors. Neuropsychopharmacology 33:2888-2899

60. Filip M, Papla I, Nowak E, Czepiel K, Przegalinski E (2003) Effects of 5-HT1B receptor ligands microinjected into the ventral tegmental area on cocaine discrimination in rats. Eur $\mathrm{J}$ Pharmacol 459:239-245

61. Filip M, Frankowska M, Zaniewska M, Golda A, Przegalinski E (2005) The serotonergic system and its role in cocaine addiction. Pharmacol Rep 57:685-700

62. Gardier AM, Gruwez B, Trillat AC, Jacquot C, Hen R, Bourin M (2001) Interaction between 5-HT(1A) and 5-HT(1B) receptors: effects of 8-OH-DPAT-induced hypothermia in 5-HT(1B) receptor knockout mice. Eur J Pharmacol 421:171-175

63. Goelet P, Castellucci VF, Schacher S, Kandel ER (1986) The long and the short of long-term memory - a molecular framework. Nature 322:419-422

64. Gohier B, Ferracci L, Surguladze SA, Lawrence E, El Hage W, Kefi MZ, Allain P, Garre JB, Le Gall D (2009) Cognitive inhibition and working memory in unipolar depression. J Affect Disord 116:100-105 
65. Greene JD, Hodges JR (1996) Identification of famous faces and famous names in early Alzheimer's disease. Relationship to anterograde episodic and general semantic memory. Brain 119(Pt 1):111-128

66. Gross C, Santarelli L, Brunner D, Zhuang X, Hen R (2000) Altered fear circuits in 5-HT(1A) receptor KO mice. Biol Psychiatry 48:1157-1163

67. Harrison AA, Parsons LH, Koob GF, Markou A (1999) RU 24969, a 5-HT1A/1B agonist, elevates brain stimulation reward thresholds: an effect reversed by GR 127935, a 5-HT1B/1D antagonist. Psychopharmacology (Berl) 141:242-250

68. Hattori M, Minato N (2003) Rap1 GTPase: functions, regulation, and malignancy. J Biochem 134:479-484

69. Hebb DO (1949) The organization of behaviour. Wiley, NewYork

70. Hemmings SM, Kinnear CJ, Niehaus DJ, Moolman-Smook JC, Lochner C, Knowles JA, Corfield VA, Stein DJ (2003) Investigating the role of dopaminergic and serotonergic candidate genes in obsessive-compulsive disorder. Eur Neuropsychopharmacol 13:93-98

71. Herbener ES (2008) Emotional memory in schizophrenia. Schizophr Bull 34:875-887

72. Hernandez PJ, Andrzejewski ME, Sadeghian K, Panksepp JB, Kelley AE (2005) AMPA/kainate, NMDA, and dopamine D1 receptor function in the nucleus accumbens core: a contextlimited role in the encoding and consolidation of instrumental memory. Learn Mem 12:285-295

73. Herrera-Guzman I, Gudayol-Ferre E, Herrera-Guzman D, Guardia-Olmos J, Hinojosa-Calvo E, Herrera-Abarca JE (2009) Effects of selective serotonin reuptake and dual serotonergicnoradrenergic reuptake treatments on memory and mental processing speed in patients with major depressive disorder. $\mathrm{J}$ Psychiatr Res 43:855-863

74. Hong CJ, Pan GM, Tsai SJ (2004) Association study of onset age, attempted suicide, aggressive behavior, and schizophrenia with a serotonin 1B receptor (A-161T) genetic polymorphism. Neuropsychobiology 49:1-4

75. Hoplight BJ, Vincow ES, Neumaier JF (2007) Cocaine increases 5-HT1B mRNA in rat nucleus accumbens shell neurons. Neuropharmacology 52:444-449

76. Hoyer D, Middlemiss DN (1989) Species differences in the pharmacology of terminal 5-HT autoreceptors in mammalian brain. Trends Pharmacol Sci 10:130-132

77. Huang YY, Grailhe R, Arango V, Hen R, Mann JJ (1999) Relationship of psychopathology to the human serotonin1B genotype and receptor binding kinetics in postmortem brain tissue. Neuropsychopharmacology 21:238-246

78. Huang YY, Oquendo MA, Friedman JM, Greenhill LL, Brodsky B, Malone KM, Khait V, Mann JJ (2003) Substance abuse disorder and major depression are associated with the human 5HT1B receptor gene (HTR1B) G861C polymorphism. Neuropsychopharmacology 28:163-169

79. Huggenvik JI, Collard MW, Kim YW, Sharma RP (1993) Modification of the retinoic acid signaling pathway by the catalytic subunit of protein kinase-A. Mol Endocrinol 7:543-550

80. Janoshazi A, Deraet M, Callebert J, Setola V, Guenther S, Saubamea B, Manivet P, Launay JM, Maroteaux L (2007) Modified receptor internalization upon coexpression of 5-HT1B receptor and 5-HT2B receptors. Mol Pharmacol 71:1463-1474

81. Johnson MK, Kounios J, Nolde SF (1997) Electrophysiological brain activity and memory source monitoring. Neuroreport 8:1317-1320

82. Kalivas PW (2004) Glutamate systems in cocaine addiction. Curr Opin Pharmacol 4:23-29

83. Kauer-Sant'anna M, Yatham LN, Tramontina J, Weyne F, Cereser KM, Gazalle FK, Andreazza AC, Santin A, Quevedo
J, Izquierdo I, Kapczinski F (2008) Emotional memory in bipolar disorder. Br J Psychiatry 192:458-463

84. Kayser V, Elfassi IE, Aubel B, Melfort M, Julius D, Gingrich JA, Hamon M, Bourgoin S (2007) Mechanical, thermal and formalin-induced nociception is differentially altered in 5HT1A-/-, 5-HT1B-/-, 5-HT2A-/-, 5-HT3A-/- and 5-HTT-/knock-out male mice. Pain 130:235-248

85. Kia-Keating BM, Glatt SJ, Tsuang MT (2007) Meta-analyses suggest association between COMT, but not HTR1B, alleles, and suicidal behavior. Am J Med Genet B Neuropsychiatr Genet 144B:1048-1053

86. Konoroski J (1948) Conditioned reflexes and neuron organisation. Cambridge University Press, Cambridge

87. Koob GF, Le Moal M (2008) Addiction and the brain antireward system. Annu Rev Psychol 59:29-53

88. Kranzler HR, Hernandez-Avila CA, Gelernter J (2002) Polymorphism of the 5-HT1B receptor gene (HTR1B): strong withinlocus linkage disequilibrium without association to antisocial substance dependence. Neuropsychopharmacology 26:115-122

89. Lappalainen J, Long JC, Eggert M, Ozaki N, Robin RW, Brown GL, Naukkarinen H, Virkkunen M, Linnoila M, Goldman D (1998) Linkage of antisocial alcoholism to the serotonin 5-HT1B receptor gene in 2 populations. Arch Gen Psychiatry 55:989-994

90. Lau C, Ng L, Pathak S, Kuan L, Sutram M, Chapin M, Youngstrom B, Kawal R, Hawrylcycz M (2008) Brain explorer. Allen Institute for Brain Research

91. Lepage M, Sergerie K, Pelletier M, Harvey PO (2007) Episodic memory bias and the symptoms of schizophrenia. Can J Psychiatry 52:702-709

92. Lerer E, Kanyas K, Karni O, Ebstein RP, Lerer B (2006) Why do young women smoke? II. Role of traumatic life experience, psychological characteristics and serotonergic genes. Mol Psychiatry 11:771-781

93. Levitan RD, Kaplan AS, Masellis M, Basile VS, Richter MA, Kennedy JL (2006) The serotonin-1Dbeta receptor gene and severity of obsessive-compulsive disorder in women with bulimia nervosa. Eur Neuropsychopharmacol 16:1-6

94. Levy D, Jakubowski M, Burstein R (2004) Disruption of communication between peripheral and central trigeminovascular neurons mediates the antimigraine action of $5 \mathrm{HT} 1 \mathrm{~B} / 1 \mathrm{D}$ receptor agonists. Proc Natl Acad Sci U S A 101:4274-4279

95. Lidstrom AM, Bogdanovic N, Hesse C, Volkman I, Davidsson P, Blennow K (1998) Clusterin (apolipoprotein J) protein levels are increased in hippocampus and in frontal cortex in Alzheimer's disease. Exp Neurol 154:511-521

96. Lopez-Figueroa AL, Norton CS, Lopez-Figueroa MO, Armellini-Dodel D, Burke S, Akil H, Lopez JF, Watson SJ (2004) Serotonin 5-HT1A, 5-HT1B, and 5-HT2A receptor mRNA expression in subjects with major depression, bipolar disorder, and schizophrenia. Biol Psychiatry 55:225-233

97. Lorenz K (1950) The comparative method in studying innate behavior patterns. Symp Soc Exp Biol 4:221-268

98. Lucas JJ, Segu L, Hen R (1997) 5-Hydroxytryptamine1B receptors modulate the effect of cocaine on $\mathrm{c}$-fos expression: converging evidence using 5-hydroxytryptamine1B knockout mice and the 5-hydroxytryptamine1B/1D antagonist GR127935. Mol Pharmacol 51:755-763

99. Ma'ayan A, Jenkins SL, Barash A, Iyengar R (2009) Neuro2A differentiation by Galphai/o pathway. Sci Signal 2:cm1

100. Malagie I, Trillat AC, Bourin M, Jacquot C, Hen R, Gardier AM (2001) 5-HT1B Autoreceptors limit the effects of selective serotonin re-uptake inhibitors in mouse hippocampus and frontal cortex. J Neurochem 76:865-871

101. Malleret G, Hen R, Guillou JL, Segu L, Buhot MC (1999) 5HT1B receptor knock-out mice exhibit increased exploratory 
activity and enhanced spatial memory performance in the Morris water maze. J Neurosci 19:6157-6168

102. Martin GR, Humphrey PP (1994) Receptors for 5hydroxytryptamine: current perspectives on classification and nomenclature. Neuropharmacology 33:261-273

103. Matten W, Daar I, Vande Woude GF (1994) Protein kinase A acts at multiple points to inhibit Xenopus oocyte maturation. Mol Cell Biol 14:4419-4426

104. McClung CA, Nestler EJ (2008) Neuroplasticity mediated by altered gene expression. Neuropsychopharmacology 33:3-17

105. Mundo E, Richter MA, Sam F, Macciardi F, Kennedy JL (2000) Is the 5-HT(1Dbeta) receptor gene implicated in the pathogenesis of obsessive-compulsive disorder? Am J Psychiatry 157:1160 1161

106. Mundo E, Richter MA, Zai G, Sam F, McBride J, Macciardi F, Kennedy JL (2002) 5HT1Dbeta Receptor gene implicated in the pathogenesis of Obsessive-Compulsive Disorder: further evidence from a family-based association study. Mol Psychiatry 7:805-809

107. Neumaier JF, Vincow ES, Arvanitogiannis A, Wise RA, Carlezon WA Jr (2002) Elevated expression of 5-HT1B receptors in nucleus accumbens efferents sensitizes animals to cocaine. J Neurosci 22:10856-10863

108. New AS, Gelernter J, Goodman M, Mitropoulou V, Koenigsberg H, Silverman J, Siever LJ (2001) Suicide, impulsive aggression, and HTR1B genotype. Biol Psychiatry 50:62-65

109. Newman SD, Carpenter PA, Varma S, Just MA (2003) Frontal and parietal participation in problem solving in the Tower of London: fMRI and computational modeling of planning and high-level perception. Neuropsychologia 41:1668-1682

110. Nishiguchi N, Shirakawa O, Ono H, Nishimura A, Nushida $H$, Ueno Y, Maeda K (2001) No evidence of an association between 5HT1B receptor gene polymorphism and suicide victims in a Japanese population. Am J Med Genet 105:343-345

111. Nonogaki K, Nozue K, Oka Y (2006) Hyperphagia alters expression of hypothalamic 5-HT2C and 5-HT1B receptor genes and plasma des-acyl ghrelin levels in Ay mice. Endocrinology 147:5893-5900

112. O'Dell LE, Parsons LH (2004) Serotonin1B receptors in the ventral tegmental area modulate cocaine-induced increases in nucleus accumbens dopamine levels. J Pharmacol Exp Ther 311:711-719

113. O'Dell LE, Manzardo AM, Polis I, Stouffer DG, Parsons LH (2006) Biphasic alterations in serotonin-1B (5-HT1B) receptor function during abstinence from extended cocaine selfadministration. J Neurochem 99:1363-1376

114. Orsetti M, Di Brisco F, Rinaldi M, Dallorto D, Ghi P (2009) Some molecular effectors of antidepressant action of quetiapine revealed by DNA microarray in the frontal cortex of anhedonic rats. Pharmacogenet Genomics 19:600-612

115. Parsons LH, Weiss F, Koob GF (1996) Serotonin1b receptor stimulation enhances dopamine-mediated reinforcement. Psychopharmacology (Berl) 128:150-160

116. Parsons LH, Weiss F, Koob GF (1998) Serotonin1B receptor stimulation enhances cocaine reinforcement. J Neurosci 18:10078-10089

117. Parsons LH, Koob GF, Weiss F (1999) RU 24969, a 5-HT1B/1A receptor agonist, potentiates cocaine-induced increases in nucleus accumbens dopamine. Synapse 32:132-135

118. Pattij T, Broersen LM, van der Linde J, Groenink L, van der Gugten J, Maes RA, Olivier B (2003) Operant learning and differential-reinforcement-of-low-rate 36 -s responding in 5HT1A and 5-HT1B receptor knockout mice. Behav Brain Res $141: 137-145$

119. Petrides M (2002) The mid-ventrolateral prefrontal cortex and active mnemonic retrieval. Neurobiol Learn Mem 78:528-538
120. Pfaus JG, Frank A (1996) Beach Award-homologies of animal and human sexual behaviors. Horm Behav 30

121. Pineyro G, Castanon N, Hen R, Blier P (1995) Regulation of $[3 \mathrm{H}] 5-\mathrm{HT}$ release in raphe, frontal cortex and hippocampus of 5HT1B knock-out mice. Neuroreport 7:353-359

122. Pooley EC, Houston K, Hawton K, Harrison PJ (2003) Deliberate self-harm is associated with allelic variation in the tryptophan hydroxylase gene (TPH A779C), but not with polymorphisms in five other serotonergic genes. Psychol Med 33:775-783

123. Price JL, Morris JC (1999) Tangles and plaques in nondemented aging and "preclinical" Alzheimer's disease. Ann Neurol 45:358 368

124. Przegalinski E, Papla I, Siwanowicz J, Filip M (2004) Effects of 5-HT1B receptor ligands microinjected into the ventral tegmental area on the locomotor and sensitizating effects of cocaine in rats. Eur Neuropsychopharmacol 14:217-225

125. Przegalinski E, Golda A, Frankowska M, Zaniewska M, Filip M (2007) Effects of serotonin 5-HT1B receptor ligands on the cocaine- and food-maintained self-administration in rats. Eur J Pharmacol 559:165-172

126. Przegalinski E, Golda A, Filip M (2008) Effects of serotonin (5HT)(1B) receptor ligands on cocaine-seeking behavior in rats. Pharmacol Rep 60:798-810

127. Quirk GJ, Gehlert DR (2003) Inhibition of the amygdala: key to pathological states? Ann N Y Acad Sci 985:263-272

128. Quraishi S, Walshe M, McDonald C, Schulze K, Kravariti E, Bramon E, Morris RG, Murray RM, Toulopoulou T (2009) Memory functioning in familial bipolar I disorder patients and their relatives. Bipolar Disord 11:209-214

129. Ramboz S, Saudou F, Amara DA, Belzung C, Segu L, Misslin R, Buhot MC, Hen R (1996) 5-HT1B receptor knock out-behavioral consequences. Behav Brain Res 73:305-312

130. Ramboz S, Oosting R, Amara DA, Kung HF, Blier P, Mendelsohn M, Mann JJ, Brunner D, Hen R (1998) Serotonin receptor 1A knockout: an animal model of anxiety-related disorder. Proc Natl Acad Sci U S A 95:14476-14481

131. Ranganath C, Minzenberg MJ, Ragland JD (2008) The cognitive neuroscience of memory function and dysfunction in schizophrenia. Biol Psychiatry 64:18-25

132. Rawley JB, Constantinidis C (2009) Neural correlates of learning and working memory in the primate posterior parietal cortex. Neurobiol Learn Mem 91:129-138

133. Reynolds SM, Berridge KC (2001) Fear and feeding in the nucleus accumbens shell: rostrocaudal segregation of GABAelicited defensive behavior versus eating behavior. J Neurosci 21:3261-3270

134. Reynolds SM, Berridge KC (2002) Positive and negative motivation in nucleus accumbens shell: bivalent rostrocaudal gradients for GABA-elicited eating, taste "liking"/"disliking" reactions, place preference/avoidance, and fear. J Neurosci 22:7308-7320

135. Riegert C, Rothmaier AK, Leemhuis J, Sexton TJ, Neumaier JF, Cassel JC, Jackisch R (2008) Increased expression of 5-HT(1B) receptors by Herpes simplex virus gene transfer in septal neurons: New in vitro and in vivo models to study 5-HT(1B) receptor function. Brain Res Bull 76:439-453

136. Rocha BA, Ator R, Emmett-Oglesby MW, Hen R (1997) Intravenous cocaine self-administration in mice lacking 5HT1B receptors. Pharmacol Biochem Behav 57:407-412

137. Rocha BA, Scearce-Levie K, Lucas JJ, Hiroi N, Castanon N, Crabbe JC, Nestler EJ, Hen R (1998) Increased vulnerability to cocaine in mice lacking the serotonin-1B receptor. Nature 393:175-178

138. Rodriguez-Manzo G, Lopez-Rubalcava C, Hen R, FernandezGuasti A (2002) Participation of 5-HT(1B) receptors in the inhibitory actions of serotonin on masculine sexual behaviour of 
mice: pharmacological analysis in 5-HT(1B) receptor knockout mice. Br J Pharmacol 136:1127-1134

139. Rojas-Corrales MO, Berrocoso E, Mico JA (2005) Role of 5HT1A and 5-HT1B receptors in the antinociceptive effect of tramadol. Eur J Pharmacol 511:21-26

140. Rosenberg D, Groussin L, Jullian E, Perlemoine K, Bertagna X, Bertherat J (2002) Role of the PKA-regulated transcription factor CREB in development and tumorigenesis of endocrine tissues. Ann N Y Acad Sci 968:65-74

141. Rujescu D, Giegling I, Sato T, Moller HJ (2003) Lack of association between serotonin 5-HT1B receptor gene polymorphism and suicidal behavior. Am J Med Genet B Neuropsychiatr Genet 116B:69-71

142. Rutz S, Riegert C, Rothmaier AK, Buhot MC, Cassel JC, Jackisch R (2006) Presynaptic serotonergic modulation of 5-HT and acetylcholine release in the hippocampus and the cortex of 5-HT1B-receptor knockout mice. Brain Res Bull 70:81-93

143. Sanders AR, Cao Q, Taylor J, Levin TE, Badner JA, Cravchik A, Comeron JM, Naruya S, Del Rosario A, Salvi DA, Walczyk KA, Mowry BJ, Levinson DF, Crowe RR, Silverman JM, Gejman PV (2001) Genetic diversity of the human serotonin receptor 1B (HTR1B) gene. Genomics 72:1-14

144. Sarhan H, Grimaldi B, Hen R, Fillion G (2000) 5-HT1B receptors modulate release of $[3 \mathrm{H}]$ dopamine from rat striatal synaptosomes: further evidence using 5-HT moduline, polyclonal 5-HT1B receptor antibodies and 5-HT1B receptor knock-out mice. Naunyn-Schmiedebergs Arch Pharmacol 361:12-18

145. Saudou F, Amara DA, Dierich A, LeMeur M, Ramboz S, Segu L, Buhot MC, Hen R (1994) Enhanced aggressive behavior in mice lacking 5-HT1B receptor. Science 265:1875-1878

146. Scearce-Levie K, Chen JP, Gardner E, Hen R (1999) 5-HT receptor knockout mice: pharmacological tools or models of psychiatric disorders. Ann N Y Acad Sci 868:701-715

147. Schoning S, Zwitserlood P, Engelien A, Behnken A, Kugel H, Schiffbauer H, Lipina K, Pachur C, Kersting A, Dannlowski U, Baune BT, Zwanzger P, Reker T, Heindel W, Arolt V, Konrad C (2008) Working-memory fMRI reveals cingulate hyperactivation in euthymic major depression. Hum Brain Mapp 30:2746-2756

148. Seong E, Seasholtz AF, Burmeister M (2002) Mouse models for psychiatric disorders. Trends Genet 18:643-650

149. Serretti A, Kato M, Kennedy JL (2008) Pharmacogenetic studies in depression: a proposal for methodologic guidelines. Pharmacogenomics J 8:90-100

150. Shanahan NA, Holick Pierz KA, Masten VL, Waeber C, Ansorge M, Gingrich JA, Geyer MA, Hen R, Dulawa SC (2009) Chronic reductions in serotonin transporter function prevent 5-HT1Binduced behavioral effects in mice. Biol Psychiatry 65:401-408

151. Sherrington CS (1906) Integrated action of the nervous system. Cambridge University Press, Cambridge

152. Shibuya EK (2003) G2 cell cycle arrest - a direct link between PKA and Cdc25C. Cell Cycle 2:39-41

153. Shippenberg TS, Hen R, He M (2000) Region-specific enhancement of basal extracellular and cocaine-evoked dopamine levels following constitutive deletion of the Serotonin(1B) receptor. J Neurochem 75:258-265

154. Sibille E, Su J, Leman S, Le Guisquet AM, Ibarguen-Vargas Y, Joeyen-Waldorf J, Glorioso C, Tseng GC, Pezzone M, Hen R, Belzung C (2007) Lack of serotonin1B receptor expression leads to age-related motor dysfunction, early onset of brain molecular aging and reduced longevity. Mol Psychiatry 12:1042-1056; 975

155. Simons JS, Spiers HJ (2003) Prefrontal and medial temporal lobe interactions in long-term memory. Nat Rev Neurosci 4:637-648

156. Slassi A (2002) Recent advances in 5-HT1B/1D receptor antagonists and agonists and their potential therapeutic applications. Curr Top Med Chem 2:559-574
157. Smith KS, Tindell AJ, Aldridge JW, Berridge KC (2009) Ventral pallidum roles in reward and motivation. Behav Brain Res 196:155-167

158. Smits KM, Smits LJ, Schouten JS, Stelma FF, Nelemans P, Prins MH (2004) Influence of SERTPR and STin2 in the serotonin transporter gene on the effect of selective serotonin reuptake inhibitors in depression: a systematic review. Mol Psychiatry 9:433-441

159. Solomon RL, Corbit JD (1974) An opponent-process theory of motivation. I. Temporal dynamics of affect. Psychol Rev 81:119-145

160. Soyka M, Preuss UW, Koller G, Zill P, Bondy B (2004) Association of 5-HT1B receptor gene and antisocial behavior in alcoholism. J Neural Transm 111:101-109

161. Squire LR, Paller KA (2000) Biology of memory. In: Sadock BJ, Sadock VA (eds) Kaplan \& Sadock's comprehensive textbook of psychiatry, 7th edn. Lippincott Williams \& Wilkins Publishers, New York

162. Stark KL, Hen R (1999) Knockout corner. Int J Neuropsychopharmacol 2:145-150

163. Stark KL, Oosting RS, Hen R (1998) Inducible knockout strategies to probe the functions of 5-HT receptors. Ann N Y Acad Sci 861:57-66

164. Stefulj J, Buttner A, Skavic J, Zill P, Balija M, Eisenmenger W, Bondy B, Jernej B (2004) Serotonin 1B (5HT-1B) receptor polymorphism (G861C) in suicide victims: association studies in German and Slavic population. Am J Med Genet B Neuropsychiatr Genet 127B:48-50

165. Stratford TR, Kelley AE (1997) GABA in the nucleus accumbens shell participates in the central regulation of feeding behavior. J Neurosci 17:4434-4440

166. Sun HF, Chang YT, Fann CS, Chang CJ, Chen YH, Hsu YP, Yu WY, Cheng AT (2002) Association study of novel human serotonin 5-HT(1B) polymorphisms with alcohol dependence in Taiwanese Han. Biol Psychiatry 51:896-901

167. Svenningsson P, Chergui K, Rachleff I, Flajolet M, Zhang X, El Yacoubi M, Vaugeois JM, Nomikos GG, Greengard P (2006) Alterations in 5-HT1B receptor function by p11 in depressionlike states. Science 311:77-80

168. Tinbergen N (1951) The study of instinct. Clarendon Press, Oxford

169. Trillat AC, Malagie I, Scearce K, Pons D, Anmella MC, Jacquot C, Hen R, Gardier AM (1997) Regulation of serotonin release in the frontal cortex and ventral hippocampus of homozygous mice lacking 5-HT1B receptors: in vivo microdialysis studies. J Neurochem 69:2019-2025

170. Trillat AC, Malagie I, Bourin M, Jacquot C, Hen R, Gardier AM (1998) Homozygote mice deficient in serotonin 5-HT1B receptor and antidepressant effect of selective serotonin reuptake inhibitors. C R Seances Soc Biol Fil 192:1139-1147

171. Tsai SJ, Wang YC, Chen JY, Hong CJ (2003) Allelic variants of the tryptophan hydroxylase (A218C) and serotonin 1B receptor (A-161T) and personality traits. Neuropsychobiology 48:68-71

172. Tsai SJ, Hong CJ, Yu YW, Chen TJ, Wang YC, Lin WK (2004) Association study of serotonin 1B receptor (A-161T) genetic polymorphism and suicidal behaviors and response to fluoxetine in major depressive disorder. Neuropsychobiology $50: 235-238$

173. Turecki G, Sequeira A, Gingras Y, Seguin M, Lesage A, Tousignant M, Chawky N, Vanier C, Lipp O, Benkelfat C, Rouleau GA (2003) Suicide and serotonin: study of variation at seven serotonin receptor genes in suicide completers. Am J Med Genet B Neuropsychiatr Genet 118B:36-40

174. Uncapher MR, Wagner AD (2009) Posterior parietal cortex and episodic encoding: insights from fMRI subsequent memory effects and dual-attention theory. Neurobiol Learn Mem 91:139-154 
175. Varnas K, Hall H, Bonaventure P, Sedvall G (2001) Autoradiographic mapping of 5-HT(1B) and 5-HT(1D) receptors in the post mortem human brain using $[(3) \mathrm{H}] \mathrm{GR}$ 125743. Brain Res 915:47-57

176. Videtic A, Pungercic G, Pajnic IZ, Zupanc T, Balazic J, Tomori M, Komel R (2006) Association study of seven polymorphisms in four serotonin receptor genes on suicide victims. Am J Med Genet B Neuropsychiatr Genet 141B:669-672

177. Wagner AD, Schacter DL, Rotte M, Koutstaal W, Maril A, Dale AM, Rosen BR, Buckner RL (1998) Building memories: remembering and forgetting of verbal experiences as predicted by brain activity. Science 281:1188-1191

178. Watakabe A, Komatsu Y, Sadakane O, Shimegi S, Takahata T, Higo N, Tochitani S, Hashikawa T, Naito T, Osaki H, Sakamoto $\mathrm{H}$, Okamoto M, Ishikawa A, Hara SI, Akasaki T, Sato H, Yamamori T (2008) Enriched expression of serotonin 1B and 2A receptor genes in macaque visual cortex and their bidirectional modulatory effects on neuronal responses. Cereb Cortex 19:1915-1928

179. Werner NS, Meindl T, Materne J, Engel RR, Huber D, Riedel M, Reiser M, Hennig-Fast K (2009) Functional MRI study of memory-related brain regions in patients with depressive disorder. J Affect Disord doi:10.1016/j.jad.2009.03.003

180. Wheeler RA, Carelli RM (2006) The neuroscience of pleasure. Focus on "Ventral pallidum firing codes hedonic reward: when a bad taste turns good". J Neurophysiol 96:2175-2176
181. Wolff M, Benhassine N, Costet P, Hen R, Segu L, Buhot MC (2003) Delay-dependent working memory impairment in youngadult and aged 5-HT1BKO mice as assessed in a radial-arm water maze. Learn Mem 10:401-409

182. Wolff M, Savova M, Malleret G, Hen R, Segu L, Buhot MC (2003) Serotonin 1B knockout mice exhibit a task-dependent selective learning facilitation. Neurosci Lett 338:1-4

183. Wurch T, Colpaert FC, Pauwels PJ (1998) Chimeric receptor analysis of the ketanserin binding site in the human 5Hydroxytryptamine1D receptor: importance of the second extracellular loop and fifth transmembrane domain in antagonist binding. Mol Pharmacol 54:1088-1096

184. Yeh ZT, Hua MS (2009) Effects of depressive disorder on false memory for emotional information. Depress Anxiety 26:456463

185. Zhang X, Andren PE, Greengard P, Svenningsson P (2008) Evidence for a role of the 5-HT1B receptor and its adaptor protein, p11, in L-DOPA treatment of an animal model of Parkinsonism. Proc Natl Acad Sci U S A 105:2163-2168

186. Zhuang X, Gross C, Santarelli L, Compan V, Trillat AC, Hen R (1999) Altered emotional states in knockout mice lacking 5-HT1A or 5-HT1B receptors. Neuropsychopharmacology 21:52S-60S

187. Zouk H, McGirr A, Lebel V, Benkelfat C, Rouleau G, Turecki G (2007) The effect of genetic variation of the serotonin 1B receptor gene on impulsive aggressive behavior and suicide. Am J Med Genet B Neuropsychiatr Genet 144B:996-1002 